Taís Cabral Monteiro

\title{
Cidade, pintura: reminiscências
}

Dissertação apresentada ao Programa de Pós-Graduação em Artes Visuais, Área de Concentração Poéticas Visuais, Linha de Pesquisa Processos de Criação em Artes

Visuais, da Escola de Comunicações e Artes da Universidade de São Paulo, como exigência parcial para obtenção do Título de Mestre em Artes, sob a orientação do Prof. Dr. Marco Garaude Giannotti.

São Paulo

2009 
Taís Cabral Monteiro

\section{Cidade, pintura: reminiscências}

Dissertação apresentada ao Programa de Pós-Graduação em Artes Visuais, Área de Concentração Poéticas Visuais, Linha de Pesquisa Processos de Criação em Artes Visuais, da Escola de Comunicações e Artes da Universidade de São Paulo, como exigência parcial para obtenção do Título de Mestre em Artes, sob a orientação do Prof. Dr. Marco Garaude Giannotti.

São Paulo

2009 


\section{Orientador}

Prof. Dr. Marco Garaude Giannotti

\section{Comissão Examinadora}

Profa. Dra. Leda Catunda

Prof. Dr. Marco Francesco Buti 
Para Ricardo Benitez. 
Agradecimentos

À Universidade de São Paulo, à Comissão de Pós-Graduação da Escola de Comunicação e Artes e ao Departamento de Artes Plásticas; ao Centro Universitário Belas Artes de São Paulo e à coordenação do Bacharelado em Artes Visuais; à Galeria Nara Roesler;

ao orientador desta pesquisa, Prof. Dr. Marco Garaude Giannotti, e à comissão examinadora dos processos de qualificação e defesa, Prof. Dr. Marco Francesco Buti e Profa. Dra. Leda Catunda, que muito contribuíram e tornaram possível a existência dessa dissertação;

à Helena Freddi, Kátia Salvanny, Francisco Maringelli, Carlos Augusto Sampaio, Olga Gouveia, Priscila Killing, Sérgio Barrero, Luciano Teixeira, David Grecov, Eurico Lopes, Eliana Barcelos, Amanda Bonadio, Adrienne Firmo, Michele Massatelli, Bruna Kim, Ricardo Benitez, Gisele, Julia e José Roberto Maramaldo; Luciane Monteiro, Beatrice e Daniele Assenti; Viviane, Ana Luísa, Maria Carolina e Alexandre Proença; Yara Moema e Carlos Roberto Franchetto Torres Monteiro, meus pais;

agradeço a todos, pelo apoio, colaboração e amizade; são muito queridos e contribuíram imensamente para o desenvolvimento deste trabalho. 
A pesquisa envolve questões da linguagem pictórica, como cor, forma, planos de representação, transparência e opacidade, espaço e superfície material, relacionando-as com o indivíduo e a cidade, através da reminiscência dos deslocamentos vivenciados cotidianamente na cidade de São Paulo.

Tais questões surgiram a partir da pesquisa teórica e do fazer artístico, utilizando procedimentos de pintura, litografia e instalação com o uso de materiais como a tinta a óleo, placas de pisos do tipo paviflex e decorflex, chapas de MDF $^{1}$, telas, fita adesiva e papéis, entre outros.

Resulta na produção e apresentação de um conjunto de obras e do desenvolvimento do presente texto de maneira a explicitar os processos teóricos e práticos utilizados durante a pesquisa, sendo acompanhado de reproduções fotográficas de parte das obras referidas nesta dissertação.

\section{Palavras-chave}

Arte pintura cidade reminiscência percepção

\section{Abstract}

This research deals with issues of pictorial language, such as color, form, planes of representation, transparency and opacity, space and material surface, and relates those with the individual and the city through reminiscence of everyday displacements in the city of Sao Paulo.

Such issues arose from a theoretical research and by artistic practice, with the use of painting, lithography, and installation procedures where materials such as oil paints, "paviflex" and "decorflex" flexible pavement tiles, MDF $^{2}$ plates, screens, adhesive tape and paper, among others, were employed.

The result is the production and presentation of a set of works, and the development of this text that explains the theoretical and practical processes applied during the research. It is accompanied by photographs of part of the works referred to in this dissertation.

\section{Keywords}

Art painting city reminiscence perception

Medium Density Fiberboard - Placa de fibra de madeira de média densidade.

Medium Density Fiberboard. 
"A palavra apenas se refere a uma coisa e esta é sempre inalcançável por mim. Cada um de nós é um símbolo que lida com símbolos - tudo ponto de apenas referência ao real. Procuramos desesperadamente encontrar identidade própria e a identidade do real. E se nos entendemos através do símbolo, é porque temos os mesmos símbolos e a mesma experiência da coisa em si: mas a realidade não tem sinônimos". 3

"Quero falar daquela tarde, porque ela deixou claro de que tipo é o domínio que as cidades exercem sobre a imaginação, e porque a cidade - onde os homens se exigem uns aos outros sem a menor consideração, onde os compromissos e telefonemas, as reuniões e visitas, os flertes e a luta pela vida não concedem ao indivíduo nenhum momento contemplativo, na hora da recordação, se vinga e o véu que ela teceu ocultamente da nossa vida mostra menos as imagens das pessoas que as dos lugares onde nós nos encontramos com os outros ou conosco mesmos."

3 Clarice Lispector. Água Viva. São Paulo: Círculo do livro SA, 1973, p. 73.

Walter Benjamin, apud Willi Bolle. Fisiognomia da metrópole moderna: representação da história em Walter Benjamin. São Paulo: Edusp, 1994, p. 336. 


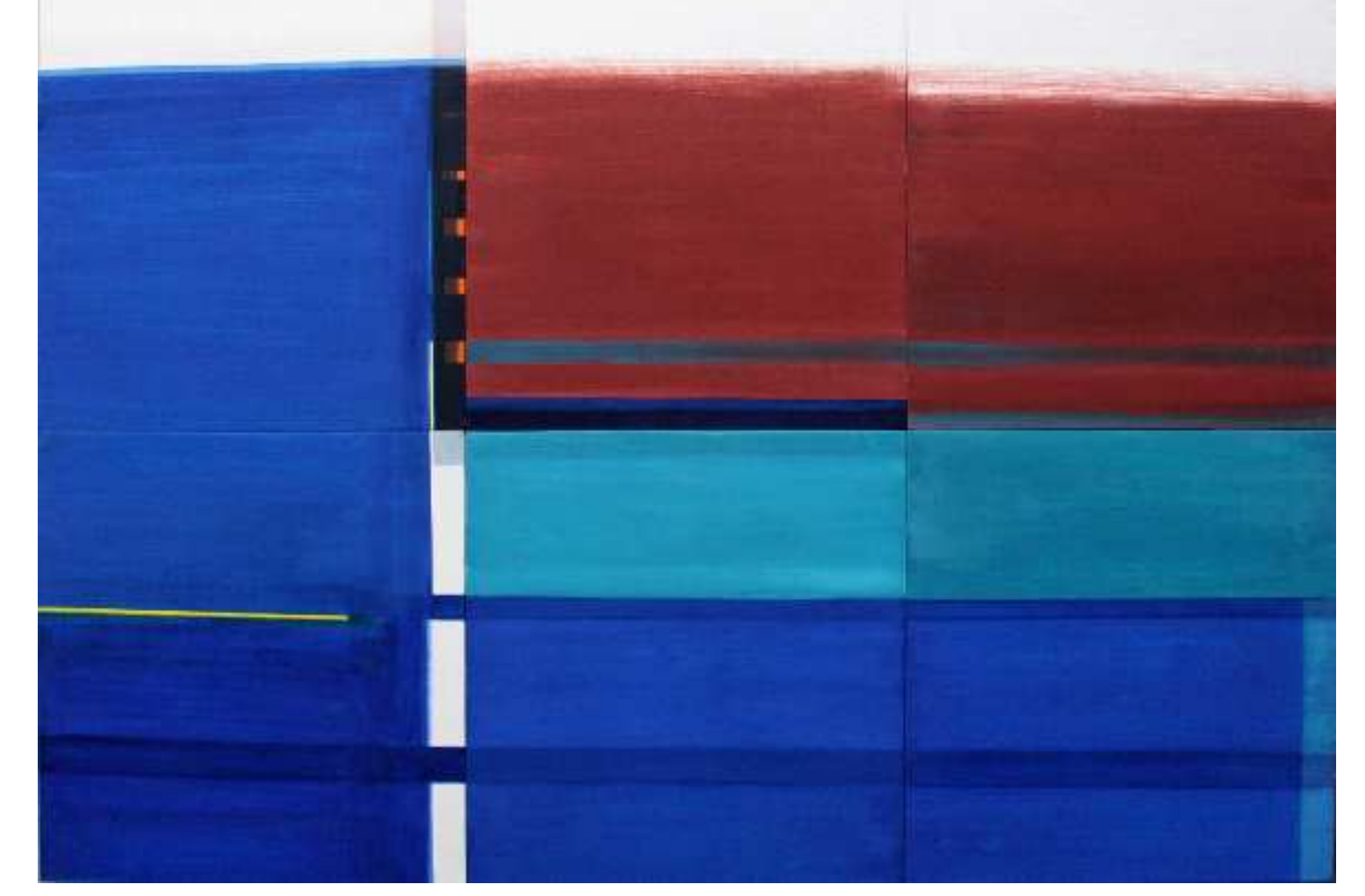


sem título, 2009, tinta a óleo sobre MDF, 80,0 x 120,0 cm. 08

sem título, 2002, tinta a óleo sobre MDF, 30,0 x 30,0 cm. 12

sem título, 2003, tinta a óleo sobre MDF, $30,0 \times 30,0 \mathrm{~cm}$. 14

sem título, 2003, tinta a óleo sobre MDF, 30,0 x 30,0 cm. 15

sem título, 2007, tinta a óleo sobre MDF, 50,0 x 50,0 cm. 18

sem título, 2007, tinta a óleo sobre MDF, 50,0 x 50,0 cm. 19

sem título, 2001, tinta a óleo sobre piso paviflex, $35,0 \times 35,0 \mathrm{~cm}$. 21

sem título, 2008, tinta a óleo sobre MDF, 50,0 x 50,0 cm. 24

Exposição na Editora Annablume, São Paulo 2005. (vista parcial) 26

sem título, 2005, tinta a óleo sobre piso paviflex, $35,0 \times 35,0 \mathrm{~cm}$. 28

sem título, 2009, tinta a óleo sobre MDF, 100,0 x 100,0 cm. 29

Mapa, 2006, diversos materiais, dim. aprox. $400,0 \times 500,0 \mathrm{~cm}$. (vista parcial) 32

Mapa, 2006, diversos materiais, dim. aprox. 400,0 x 500,0 cm. (vista parcial) 33

Mapa, 2006, diversos materiais, dim. aprox. 400,0 x 500,0 cm. (vista parcial) 35

Mapa, 2006, diversos materiais, dim. aprox. $400,0 \times 500,0 \mathrm{~cm}$. (vista parcial) 36

Mapa, 2006, diversos materiais, dim. aprox. $400,0 \times 500,0 \mathrm{~cm}$. (vista parcial) 37

Mapa, 2006, diversos materiais, dim. aprox. $400,0 \times 500,0 \mathrm{~cm}$. (vista parcial) 38

Mapa, 2006, diversos materiais, dim. aprox. $400,0 \times 500,0 \mathrm{~cm}$. (vista parcial) $\quad 40$

crayon e tusche sobre pedra litográfica, $2009,34,0 \times 47,0 \mathrm{~cm}$. 42

crayon e tusche sobre pedra litográfica, $2009,45,0 \times 60,0 \mathrm{~cm}$. 43

sem título, litografia sobre papel Hahnemüle $300 \mathrm{~g}, 2009,46,00 \times 62,0 \mathrm{~cm}$. 45 
sem título, litografia sobre papel Hahnemüle $300 \mathrm{~g}, 2009,44,00 \times 58,0 \mathrm{~cm}$.

Piet Mondrian. Broadway Boogie-Woogie, 1942-43, óleo sobre tela, 127,0 x 127,0 cm. 56 Atelier de Mondrian em 26, Rue du Depart, 1926.

Volpi. Portas soltas, 1960, têmpera sobre tela, $94,5 \times 69,5 \mathrm{~cm}$.

Mapa, 2006, diversos materiais, dim. aprox. 400,0 x 500,0 cm. (vista parcial) 69 sem título, 2001, tinta a óleo sobre piso paviflex, 35,0 x 35,0 cm. 71

Exposição na Galeria Olido, São Paulo, 2004. (vista parcial) 72

sem título, livro de artista composto por uma litografia, 2009, 49, $5 \times 39,5 \mathrm{~cm}$. 74

Mapa, 2006, diversos materiais, dim. aprox. 400,0 x 500,0 cm. (vista parcial) 75

sem título, 2009, tinta a óleo sobre MDF, 60,0 x60,0 cm. 77

sem título, 2008, tinta a óleo sobre MDF, $50,0 \times 50,0 \mathrm{~cm}$. 79

sem título, 2009, tinta a óleo sobre tela (linho), 134,0 x 134,0 cm. 80 


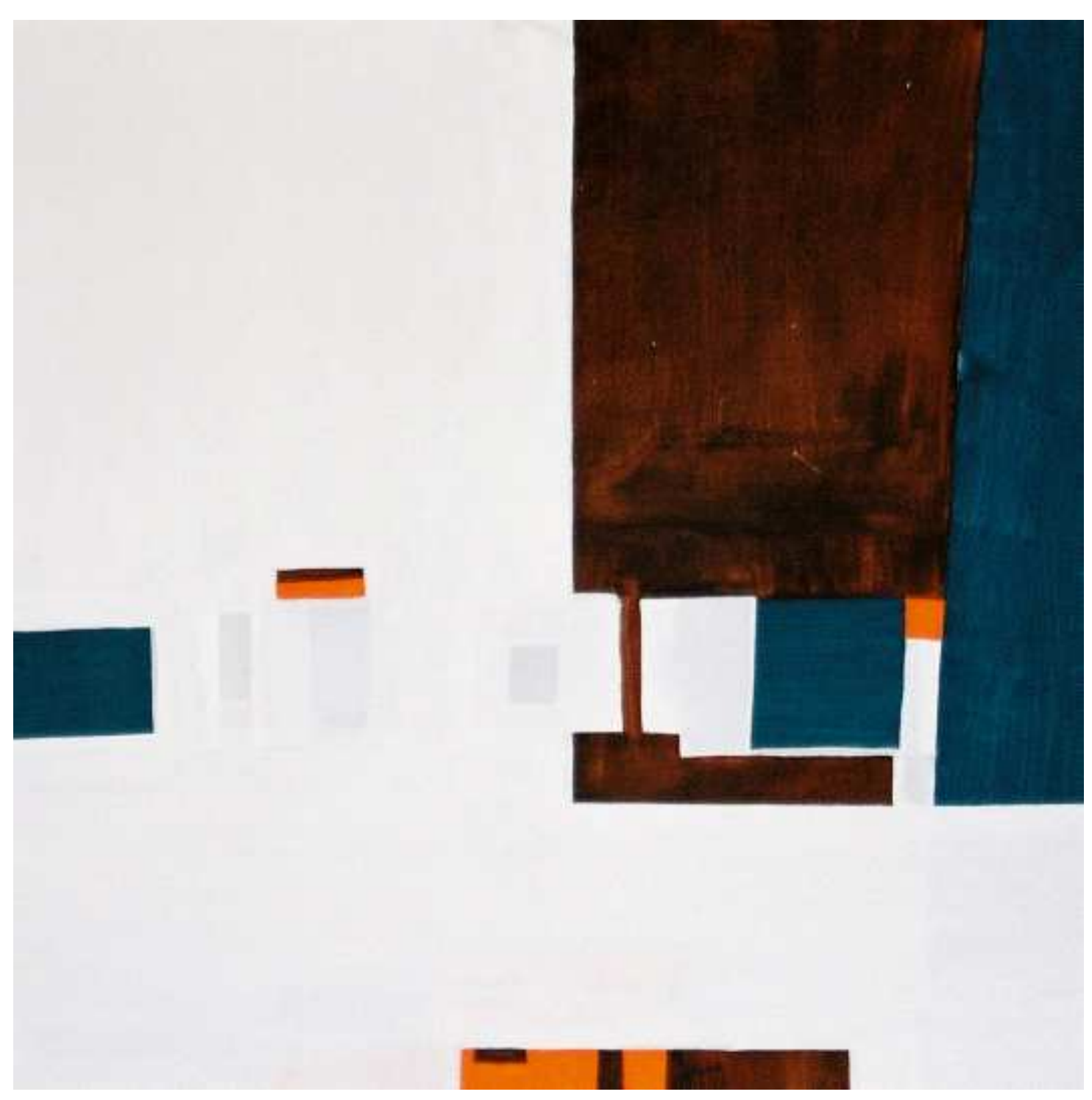




\section{Apresentação}

A presente pesquisa envolve a linguagem pictórica ${ }^{5}$. Os trabalhos que utilizam elementos gráficos e tridimensionais são menos recorrentes. Tais obras são relacionadas com a reminiscência ${ }^{6}$ do adentrar e vivenciar a cidade de São Paulo.

As frases que utilizam a primeira pessoa do singular referem-se a obras ou reflexões autorais. Buscou-se referências na produção de artistas, pesquisadores e escritores que, quando necessário, são relacionados no texto ${ }^{7}$.

No início do desenvolvimento desta pesquisa, foi possível perceber elementos da cidade nas pinturas. Serão refletidas questões surgidas a partir dos trabalhos desenvolvidos, como o diálogo entre a linguagem pictórica e o lugar vivenciado.

Acompanha ainda reproduções fotográficas de obras realizadas durante a pesquisa e de autores citados no texto.

$5 \quad$ Utilizo Linguagem Pictórica para pinturas e outros trabalhos que utilizam o vocabulário específico da pintura, como cor, forma, textura, matéria e superfície.

Busquei os termos reminiscência e rememoração na obra de Walter Benjamin, como na seguinte referência, "O importante, para o autor que rememora, não é o que ele viveu, mas o tecido de sua rememoração, o trabalho de Penélope da reminiscência, e chegamos a rememorar o que é mais próximo, mais banal, mais manifesto." Walter Benjamin. Fisiognomia da metrópole moderna: representação da história em Walter Benjamin. São Paulo: Edusp, 1994, p. 37.

A idéia de cidade pode ser abordada pelos autores de diversas maneiras, não sendo, necessariamente, a mesma cidade tratada nesta pesquisa, a cidade de São Paulo. 


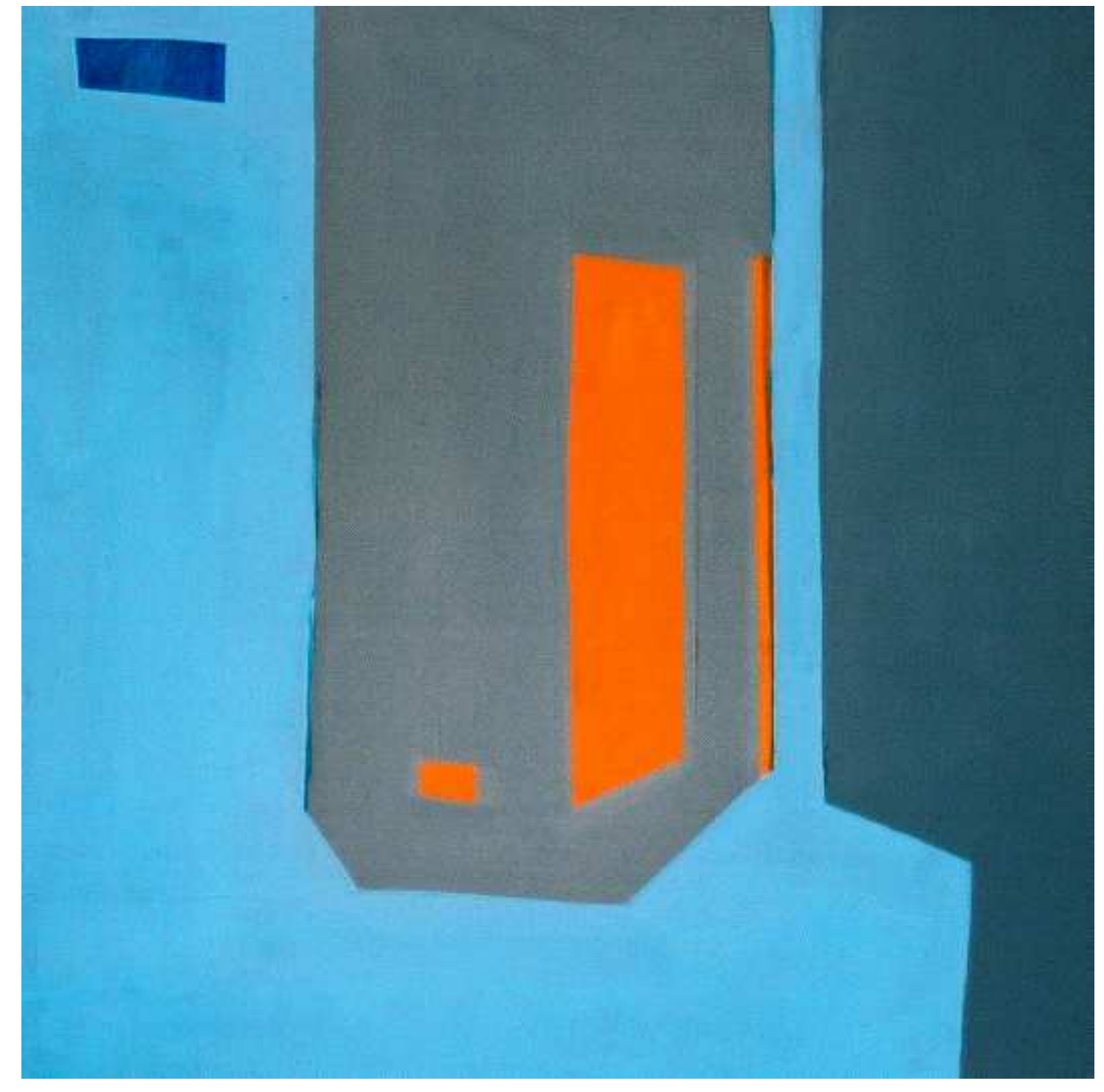




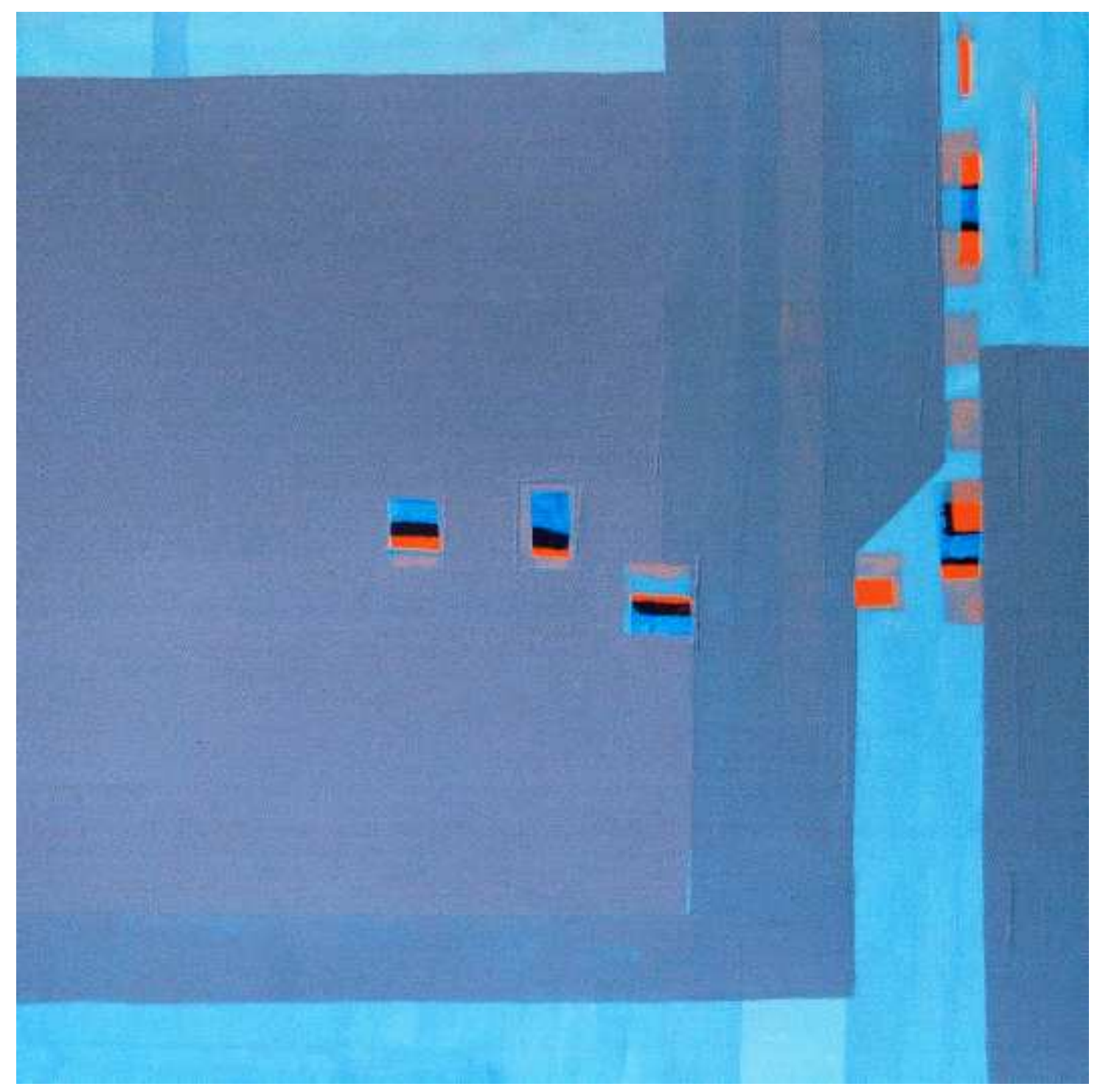


Introdução

Esta pesquisa, que começou a existir em 2001, se pauta nas imagens ${ }^{8}$ cotidianas assimiladas a partir da vivência na cidade de São Paulo.

Imagens de naturezas diversas, selecionadas pela percepção individual e acumuladas pela memória durante os deslocamentos cotidianos. Assim como criadas por processos de mapeamento da memória ${ }^{9}$ e pelo contato com os modos de representação desse espaço. Henri Bergson observou que "toda percepção está impregnada de lembrança, pela conservação integral do passado e sua articulação espontânea e livre com o presente, sendo toda percepção o resultado da interação do ambiente em que se insere o indivíduo e de seu sistema nervoso"10

Em sua relação com a cidade, percebo que o olhar pode se prender em detalhes de suas construções arquitetônicas, ordenadas ou desordenadas. Pode fazer recortes em viadutos e torres altíssimas, enquanto passa por pequenas esquinas ou vãos livres, por seus labirintos de ruas. Os ambientes percorridos, internos e externos às edificações, podem ser particularmente familiares ou

8 De maneira que a visualidade está vinculada a uma situação espacial e temporal vivenciada, portanto relacionada também aos outros sentidos da percepção. do sujeito.

Imagens captadas no presente momento podem desencadear a lembrança de outras imagens, que são associadas entre si na memória Henri Bergson. Matéria e memória. São Paulo: Martins Fontes, 1999, p. 41. 
desconhecidos. A partir das sensações experimentadas no movimento de circulação, é possível construir relações contínuas na memória e criar mapas mentais ${ }^{11}$ com os fragmentos de imagens rememorados.

A reminiscência do vivenciar a cidade torna-se a idéia inicial para os trabalhos que construo. As investigações plásticas se estendem para investigações sobre a cidade, bem como no caminho inverso.

Enquanto formação de um pensamento visual, estar na cidade (e não diante dela) impõe a fragmentação da paisagem. O olhar não consegue conter este espaço de uma só vez. Os limites do campo visual e a configuração dos elementos, não permitem um recuo contemplativo. Essa condição permite que as imagens que desenvolvo sejam vistas como uma estruturação das coisas que existem no emaranhado da cidade.

Considerando que "o espaço figurativo não é feito apenas daquilo que se vê, mas de infinitas coisas que se sabem e que se lembram, de notícias"12, a história, a cultura material e imaterial da cidade, seus modos de representação ${ }^{13}$ e interpretação, incluindo as pesquisas tecnológicas contemporâneas ${ }^{14}$, referenciam e influenciam o modo de se perceber esse lugar.

11 Os mapas mentais são entendidos como imagens decorrentes dos processos associativos da memória.

Pierre Francastel apud Giulio Carlo Argan. História da arte como história da cidade. São Paulo: Martins Fontes, 2005, p. 3

$\mathrm{Ou}$, pelo contrário, cidades que foram construídas sendo influenciadas por cidades ideais, como no período do Renascimento, quando pinturas realizadas por artistas daquela época compunham, por vezes, um modelo arquitetônico e urbanístico.

Como as imagens capturadas e compiladas diariamente por câmeras e satélites, presentes em nosso cotidiano de muitas maneiras, como nos meios de comunicação, e que podem também ser acessadas por computadores domésticos, em tempo real ou não, via Internet, ou com ferramentas como o Google Earth, que simula a espacialidade do globo terrestre. Outras são criadas virtualmente, por exemplo, para a simulação de um espaço tridimensional e real em programas de videogames. 


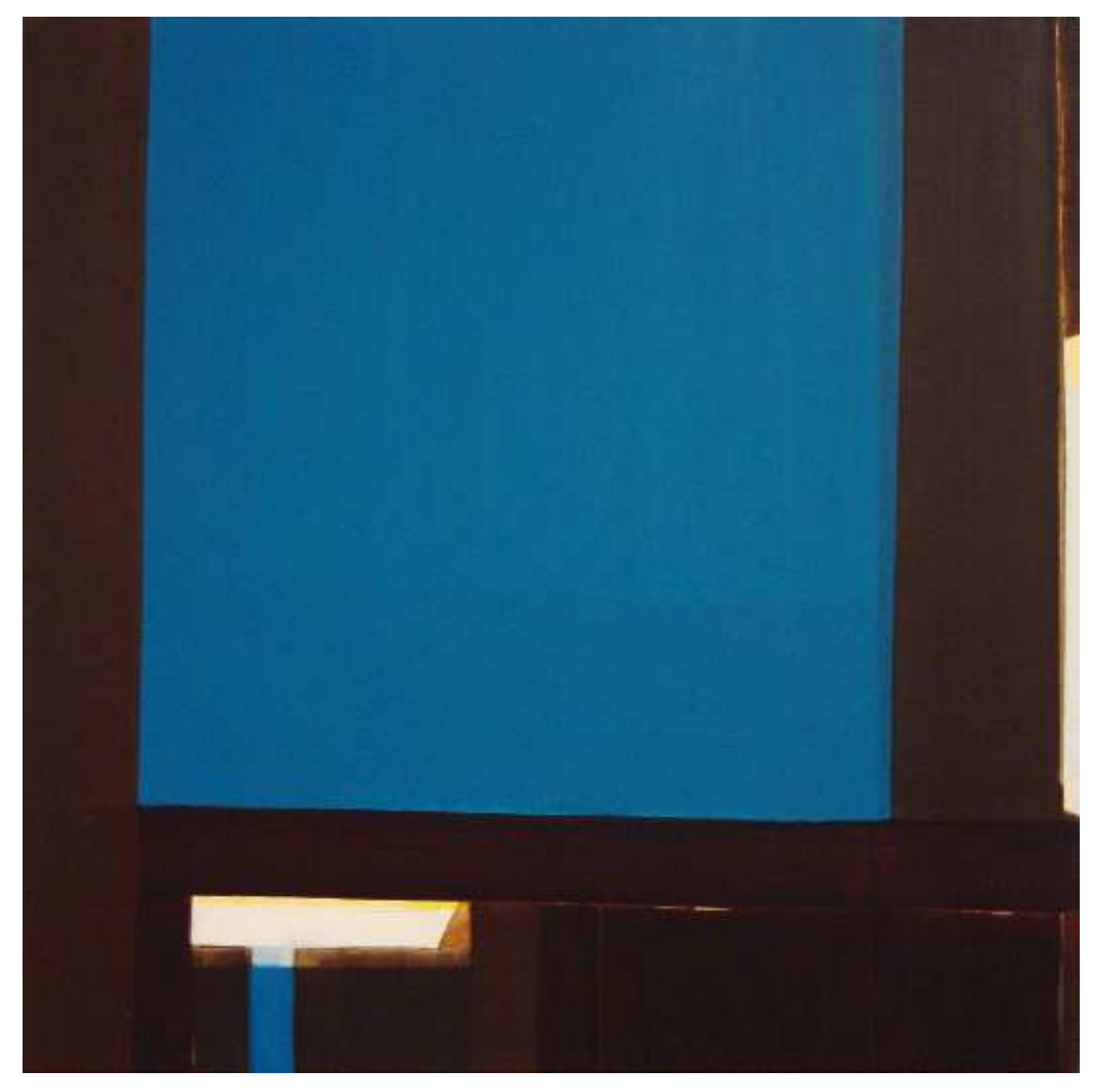




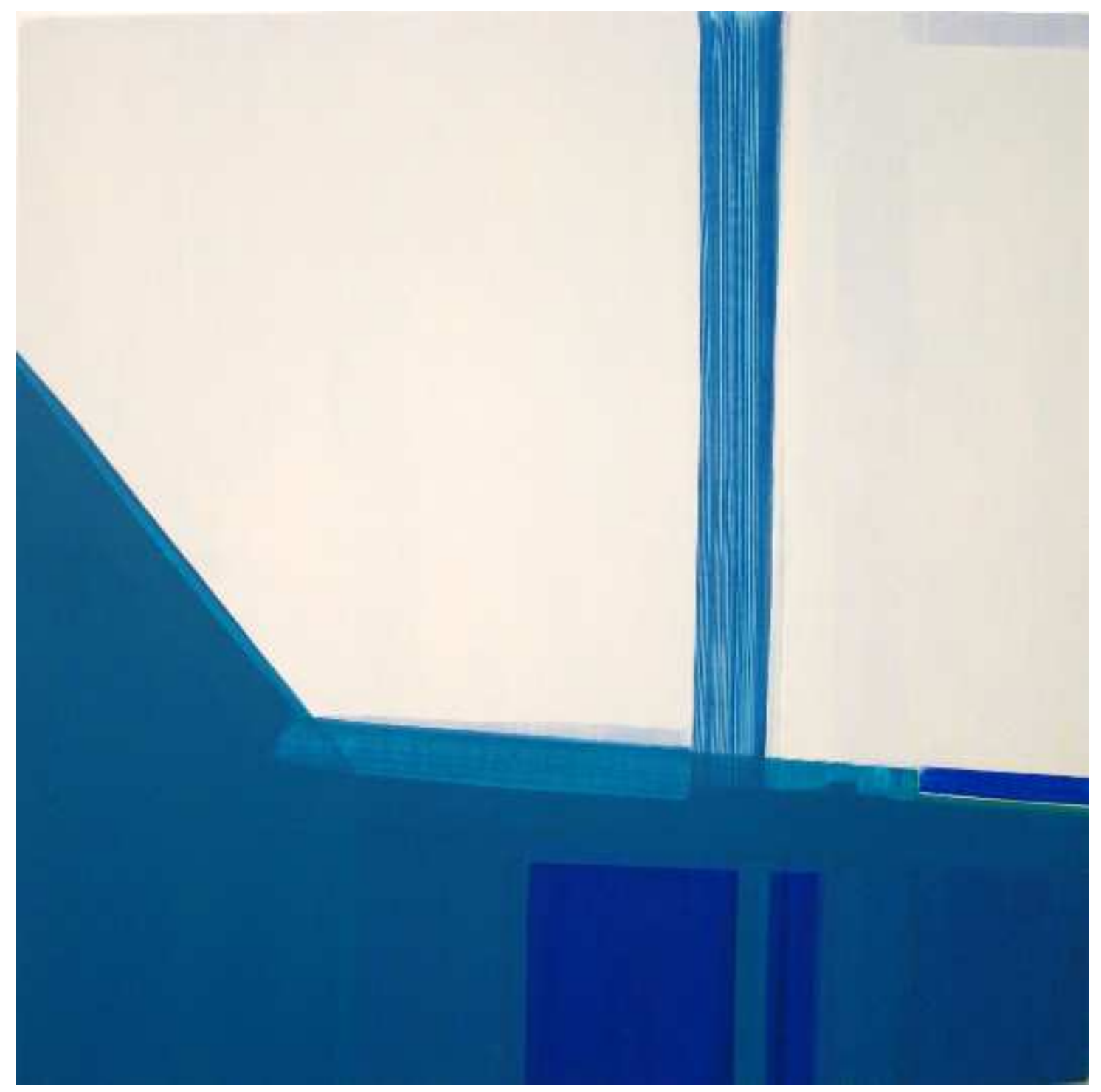




\section{Percursos}

Busco vivenciar a cidade a partir de trajetos cotidianos no espaço urbano. Para a constituição de um repertório de imagens, o reconhecimento de elementos pode ser considerado uma habilidade racional, a partir da percepção de diferenças ou semelhanças entre os objetos. ${ }^{15} \mathrm{~A}$ repetição de percursos faz com que as imagens percebidas criem novas imagens, em mapas mentais.

Os deslocamentos por construções cotidianas da arquitetura sugerem intermináveis variações de proporção, distância, forma, disposição espacial, do infinitamente grande ou pequeno. 


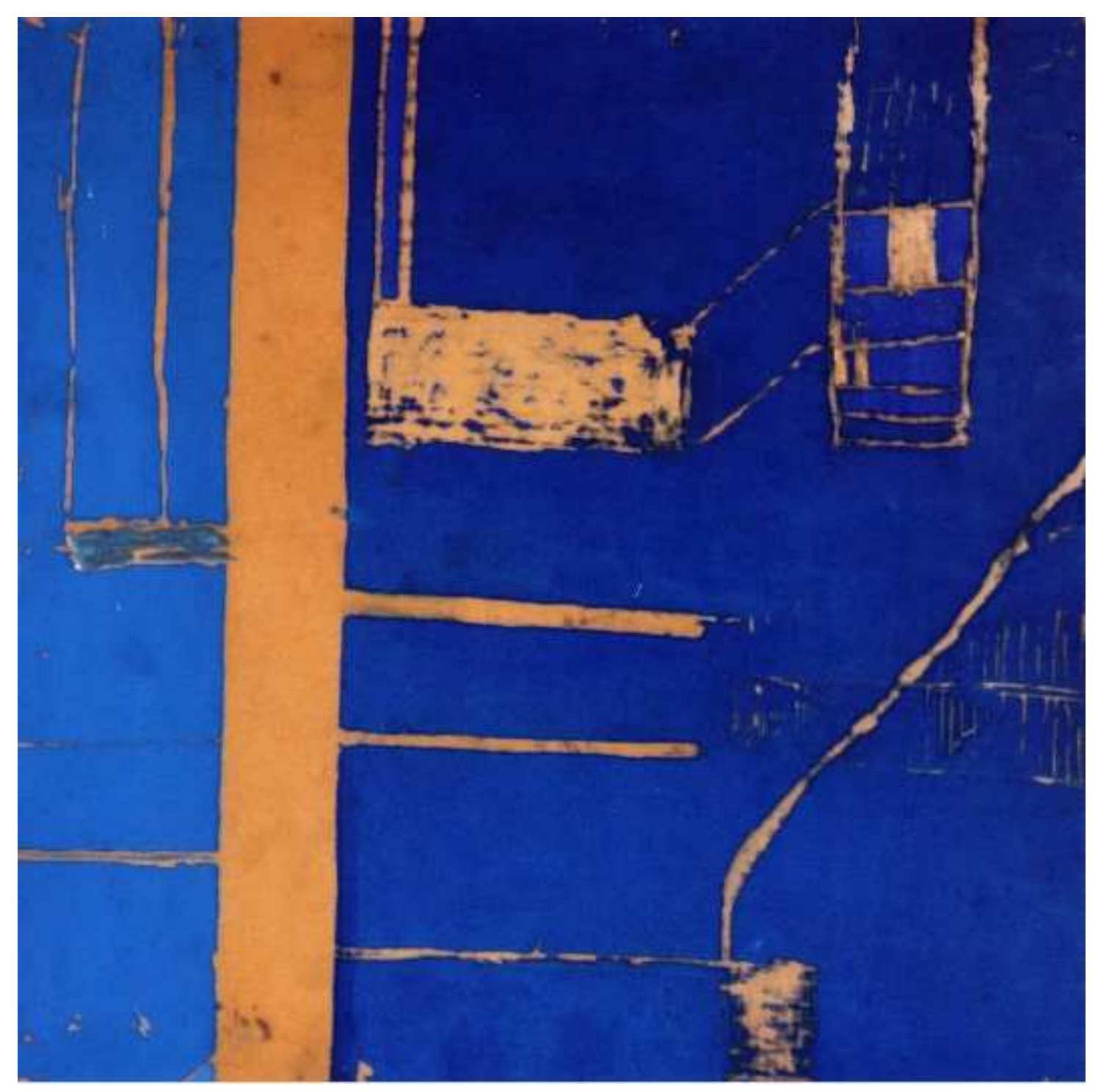


É possível adentrar a cidade diversas vezes, num mesmo dia. Por vezes, os compromissos nos obrigam a cumprir deslocamentos - a pé ou com variados meios de transporte - lineares, circulares ou labirínticos, sem sequer sair da mancha urbana.

Os trabalhos desenvolvidos podem ser pensados como resultado da experiência dos sentidos, da imaginação e da memória. Ao vivenciar a cidade é possível criar uma experiência pictórica. A criação em arte pode não ser reconhecida em sua totalidade, sendo os diferentes processos criativos passíveis de mudanças $^{16}$. "O homem da multidão", de Edgar Allan Poe é um dos primeiros textos sobre a cidade moderna. $O$ autor ambienta a vida urbana e a multidão, sua movimentação contínua e acelerada, em seus labirintos de ruas, expondo as pessoas e seu lugar como a cidade. ${ }^{17}$

16 Sobre este assunto, ver Cecília Almeida Salles. Gesto Inacabado: processo de criação artística. São Paulo: FAPESP / Annablume, 2004.

作 como aquele que observa a multidão e cada pessoa, de um ponto de vista estratégico. Sobre o assunto, ver Renato Cordeiro Gomes. Todas as cidades, a cidade. Rio de Janeiro: Rocco, 1994. 
Acredito que a vivência das pessoas na cidade desenvolva um determinado imaginário. Como o espaço urbano, as artes visuais constituem um lugar com linguagens elaboradas em sua própria instância, que possibilitam o exercício da imaginação. No livro Cidades invisíveis, de Ítalo Calvino, um personagem-viajante adentra diferentes cidades, cada uma delas descrita num conto breve. $\mathrm{O}$ autor não as situa num tempo e num espaço reconhecíveis, podendo ser qualquer cidade, ou nenhuma existente na realidade, ou muitas cidades misturadas - relembradas ou imaginadas. 


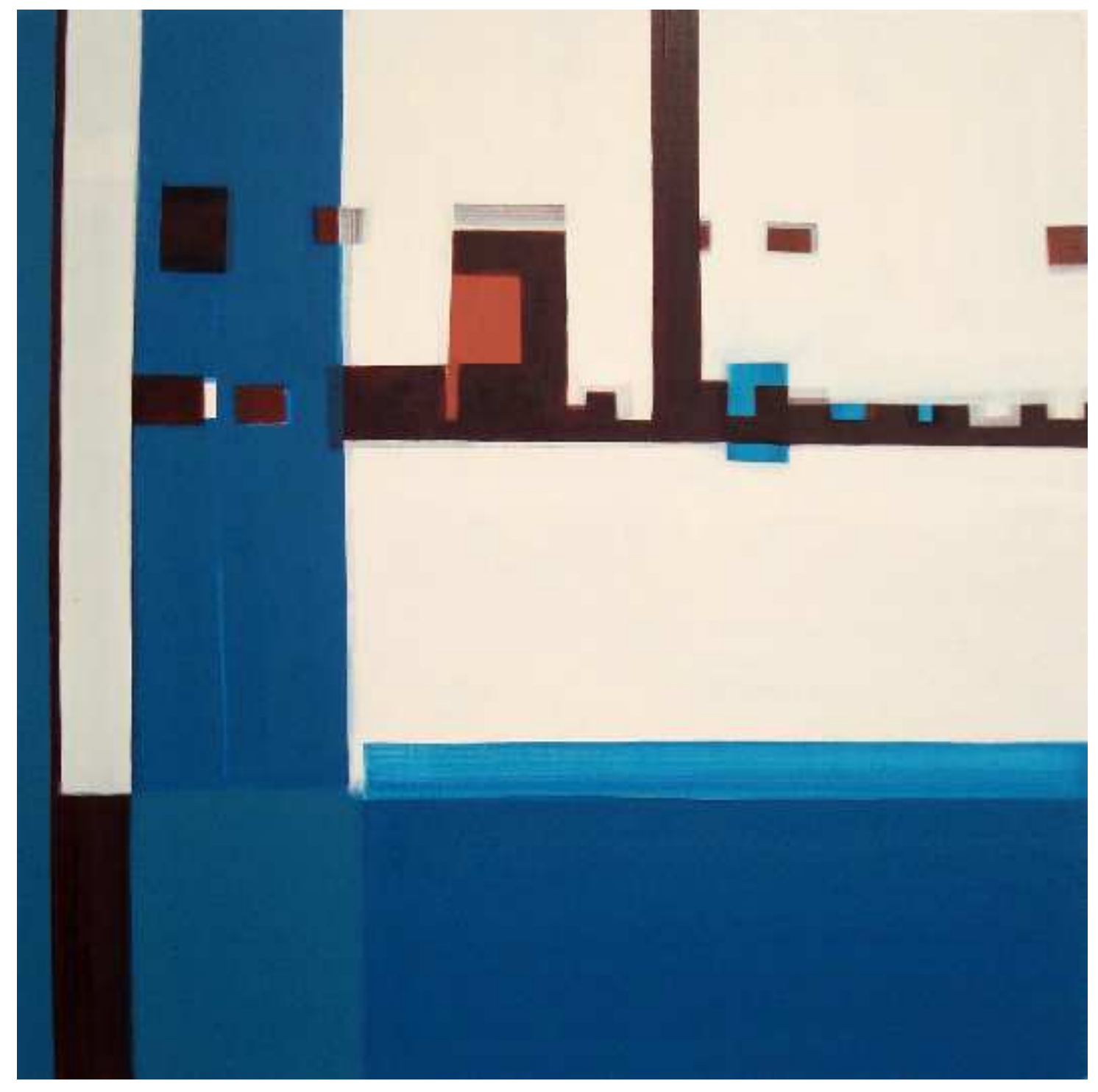


Técnica, poética e matéria

A partir do desenvolvimento das obras realizadas, que organizei como Pinturas, Litogravuras e a ocupação espacial nomeada Mapa, procurei elementos que os aproximam ou distanciam.

Em meus trabalhos, características da linguagem pictórica, como cores, formas e materialidades específicas, sugerem construções gráficas e tridimensionais, embora sejam linguagens distintas. 
Pinturas

Utilizo como suportes para as pinturas chapas de $\mathrm{MDF}^{18}$, placas de linóleo, placas de pisos paviflex e decorflex ${ }^{19}$, e telas.

Os pisos industriais tem uma forma quadrada. Os suportes permitem estruturações modulares, de maneira que podem formar quadrados ou retângulos maiores pela união das peças menores. No momento da montagem, as pinturas podem formar combinações entre si e o ambiente.

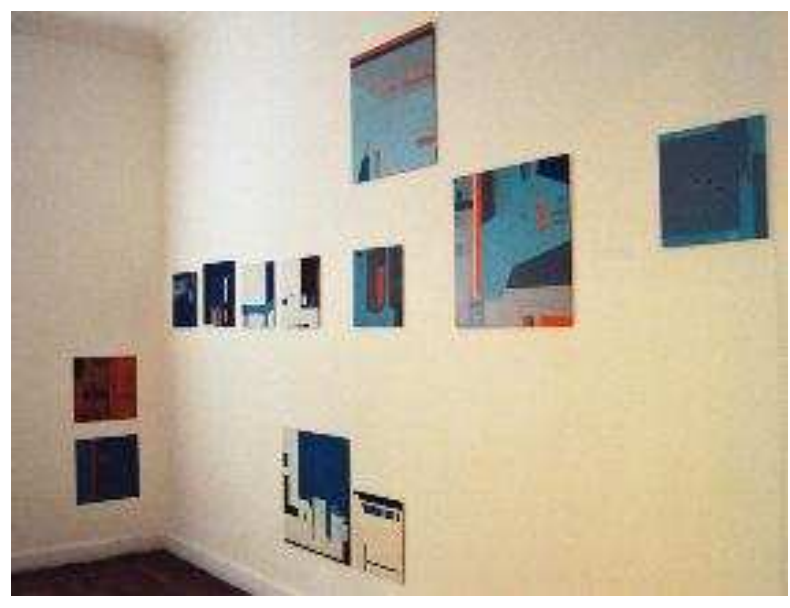

Aglomerado de madeira. Medium Fiber Density.

Tipos de piso emborrachado. 
As primeiras placas de paviflex com as quais trabalhei foram encontradas com marcas de seu uso anterior, como piso. O motivo pelo qual utilizei este suporte tem relação com sua forma, sua superfície lisa e emborrachada, e sua utilidade anterior. Esse piso específico possuía informações que evidenciavam seu uso, como sujeiras, sinais e incisões. Tais marcas geraram estímulos, de fazer novas incisões e construções pictóricas que dialogassem com a imagem já existente. Nessas pinturas, não tive vontade de cobrir inteiramente o suporte, para não apagar sua superfície, que possui cor - um tipo de laranja -, e outras informações próprias.

As chapas de MDF e telas receberam um tratamento de fundo para o qual utilizei o processo de encolagem ${ }^{20}$ e, por vezes, o de branqueamento. ${ }^{21}$ As telas foram feitas com dois tipos de tecido: Iona e linho, esticados e afixados em chassis. As chapas de MDF receberam uma estrutura por trás, também de MDF, que as deixa mais resistentes, auxilia sua fixação e cria um afastamento da superfície da parede quando montadas. Nas últimas pinturas que realizei sobre este material, uni as peças utilizadas com a dimensão de $30 \times 30 \mathrm{~cm}$ a $50 \times 50 \mathrm{~cm}$, de maneira a formar superfícies maiores, de $100 \times 100 \mathrm{~cm}, 80 \times$ $120 \mathrm{~cm}$. As linhas resultantes do encontro entre as placas menores participam da imagem da pintura, criando outro tipo de complexidade nos suportes.

20 Impermeabilização do tecido ou madeira com aplicação de cola.

21 Com fundos branqueados de base sintética, compostos por materiais como o polímero, como a tinta acrílica, ou de base orgânica, compostas por cola de origem orgânica, pigmento branco e carbonato de cálcio. 


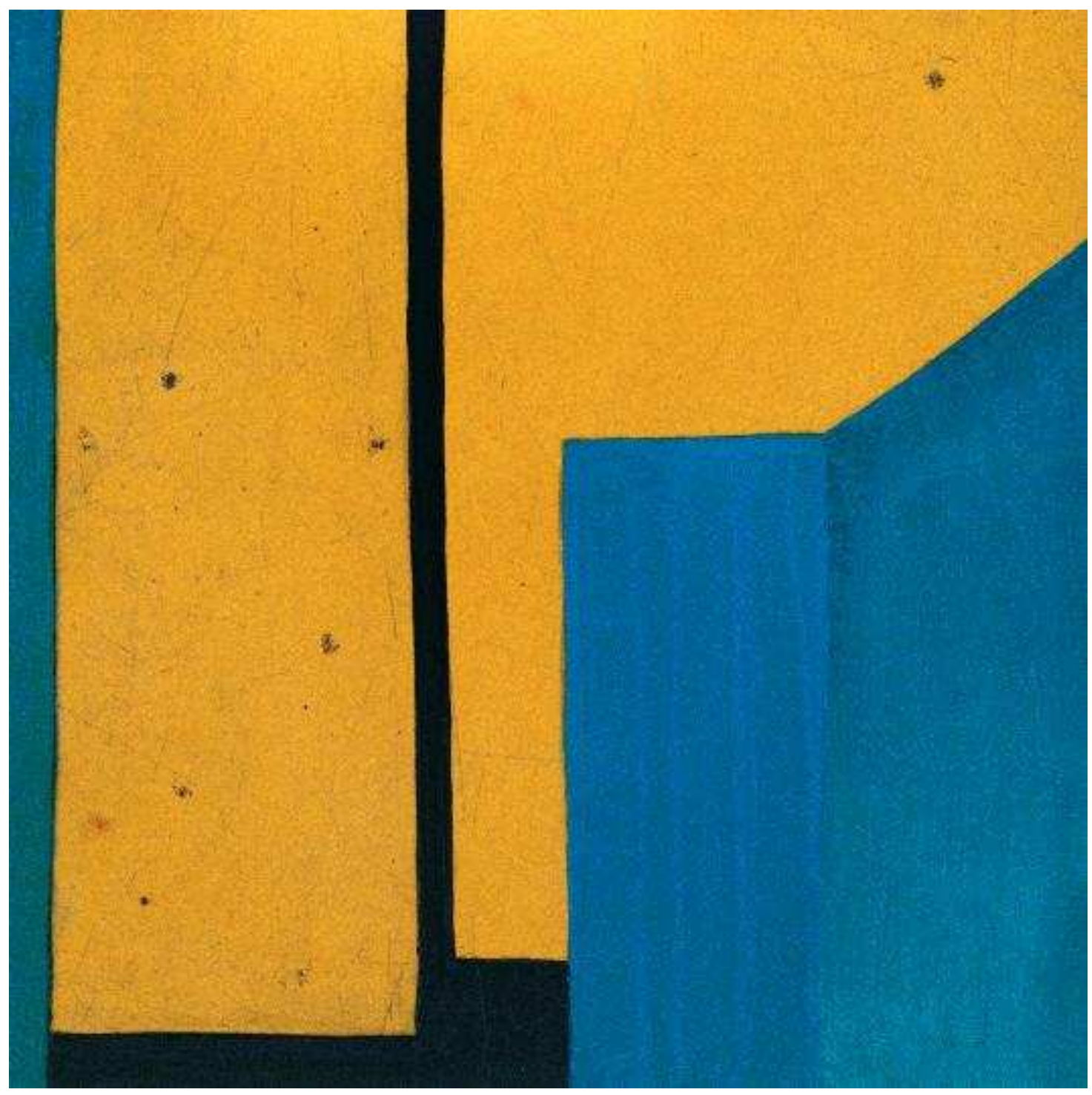




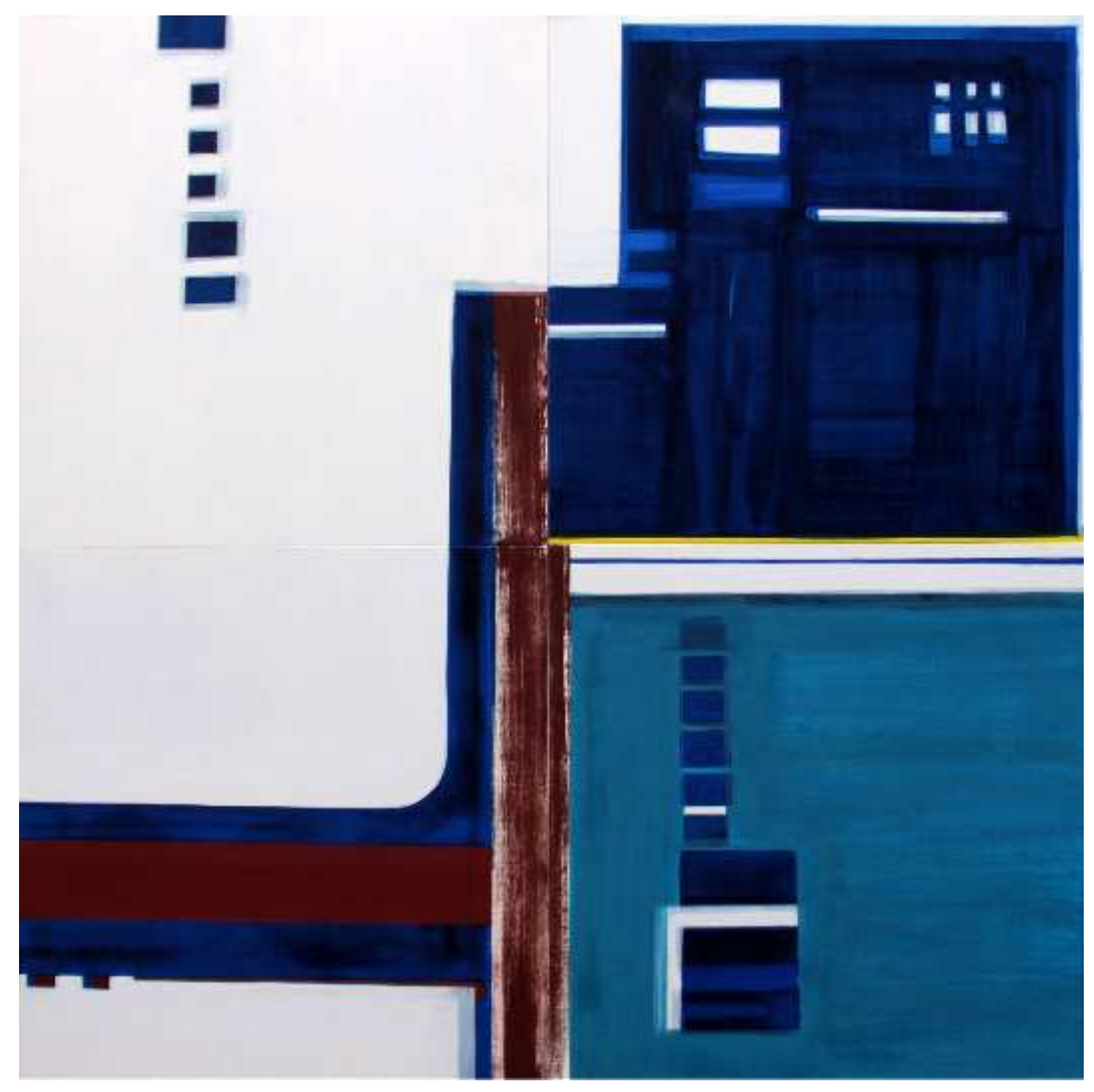


Trabalho com a tinta a óleo. sobre os o suportes. Em uma superfície rígida e lisa, a fatura pictórica se modifica. A tinta se comporta de maneira diferente do que sobre a trama do tecido - que pode ter diferentes rugosidades e se tornar mais suave, com a aplicação de fundo apropriado.

As imagens das pinturas, feitas com os pincéis e as tintas, se relacionam com a forma do material escolhido, sendo por vezes mais geometrizadas, porém não almejo um rigor geométrico. Podem lembrar formas e espacialidades da arquitetura e do urbanismo, assim como de mapas cartográficos. 
Mapa, ocupação realizada no Ateliê Amarelo22

$\mathrm{Na}$ ocupação realizada no Ateliê Amarelo, por vontade de uma espacialização do trabalho na sala, o uso de materiais foi ampliado. Busquei outros tipos de pisos, como o emborrachado do tipo grão de arroz, azulejos cerâmicos e hidráulicos. Foram utilizadas, além da tinta a óleo, tintas como a do tipo látex e a spray automotiva, assim como fita adesiva do tipo crepe e cola de contato.

22 Projeto anual de residência artística desenvolvido pela Secretaria da Cultura do Estado de São Paulo, com duração média de 6 meses, localizado do bairro da luz, Centro, São Paulo, do qual participei em 2006 da terceira de suas quatro edições. 


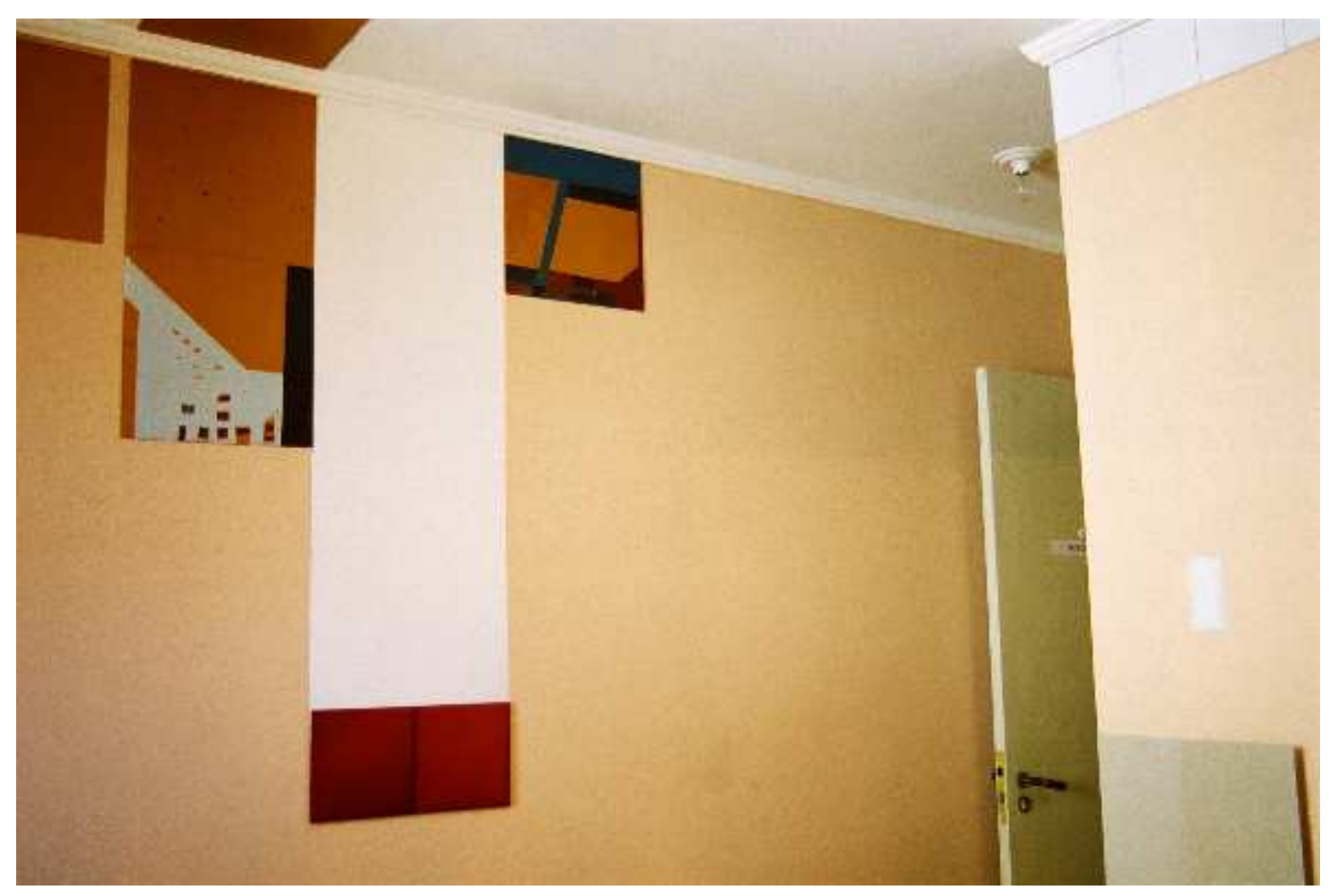




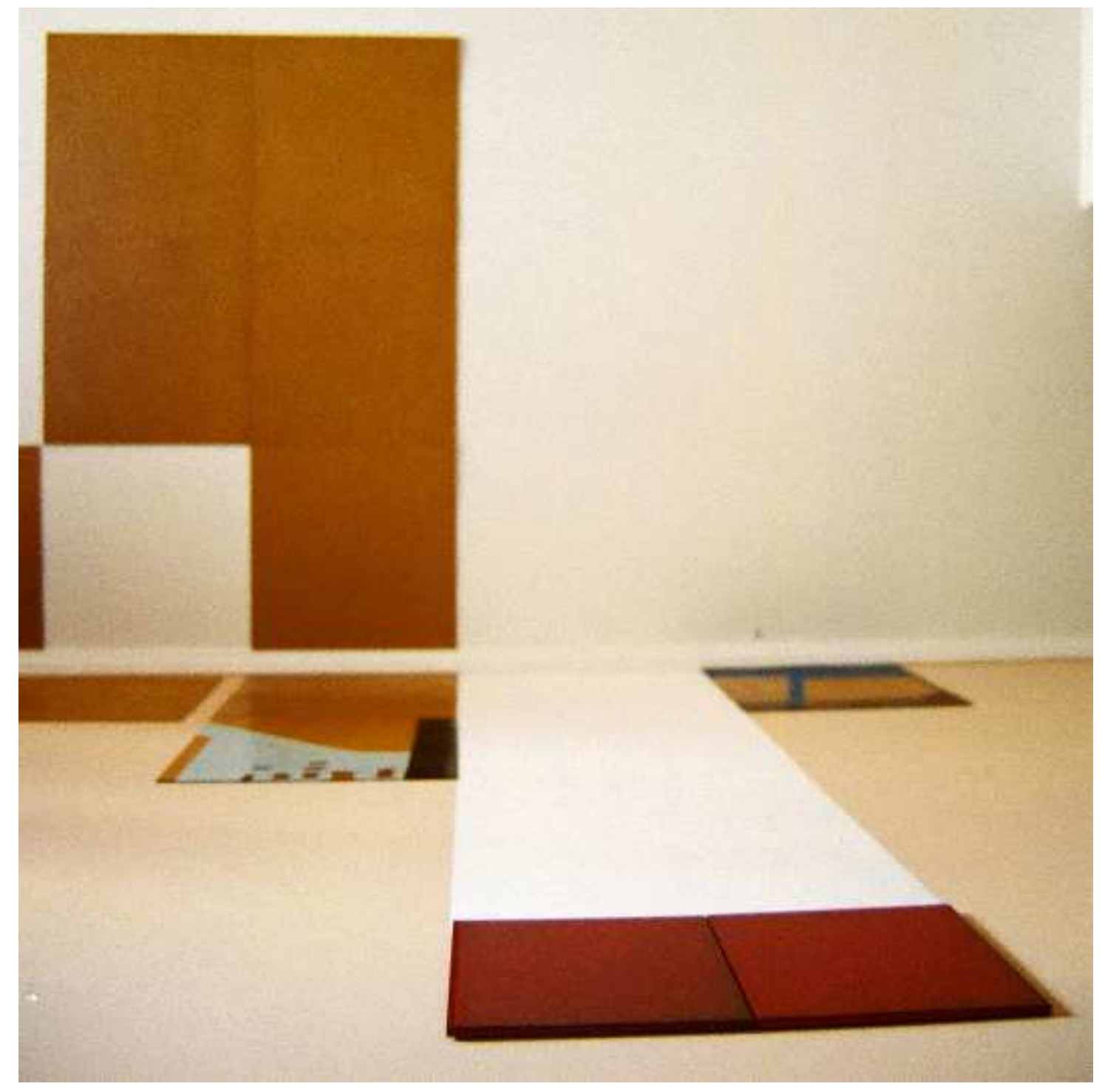


As paredes, o teto e o chão do ambiente foram ocupados pela acumulação dos materiais, que foram depositados, colados ou afixados, de maneira a delimitar espaços e criar novas formas nas superfícies da sala. Tais formas eram predominantemente quadrados e retângulos, fazendo uso dos eixos ortogonais, formados pelo encontro das paredes com o teto e o chão, ou pelo rejunte do assentamento dos azulejos, no piso original. Formas foram criadas com o apagamento do rejunte, de material escuro em relação ao piso de cor clara. Para tanto, cobri partes do rejunte com fita adesiva e tinta, unindo os azulejos. Outros pisos, sendo alguns encontrados já com sinais de uso e outros adquiridos novos e sem marcas, foram colados nas paredes e teto, produzindo novas formas. As pinturas feitas com a cor branca sobre a pintura original da parede, de cor rosada, deram continuidade ao branco do piso e do teto, o que transformou o modo de ser percebida a estrutura daquele ambiente.

As pinturas realizadas sobre placas individuais de piso paviflex ou MDF, construíram a pintura que se desenvolveu no espaço com os outros elementos materiais, que tornaram-se elementos pictóricos, como cor e forma, sendo por vezes sobrepostos. Acabaram por se unir com as paredes, a janela, o piso e o teto, e com seus utensílios específicos - objetos que fazem parte de suas instalações elétricas e hidráulicas. 


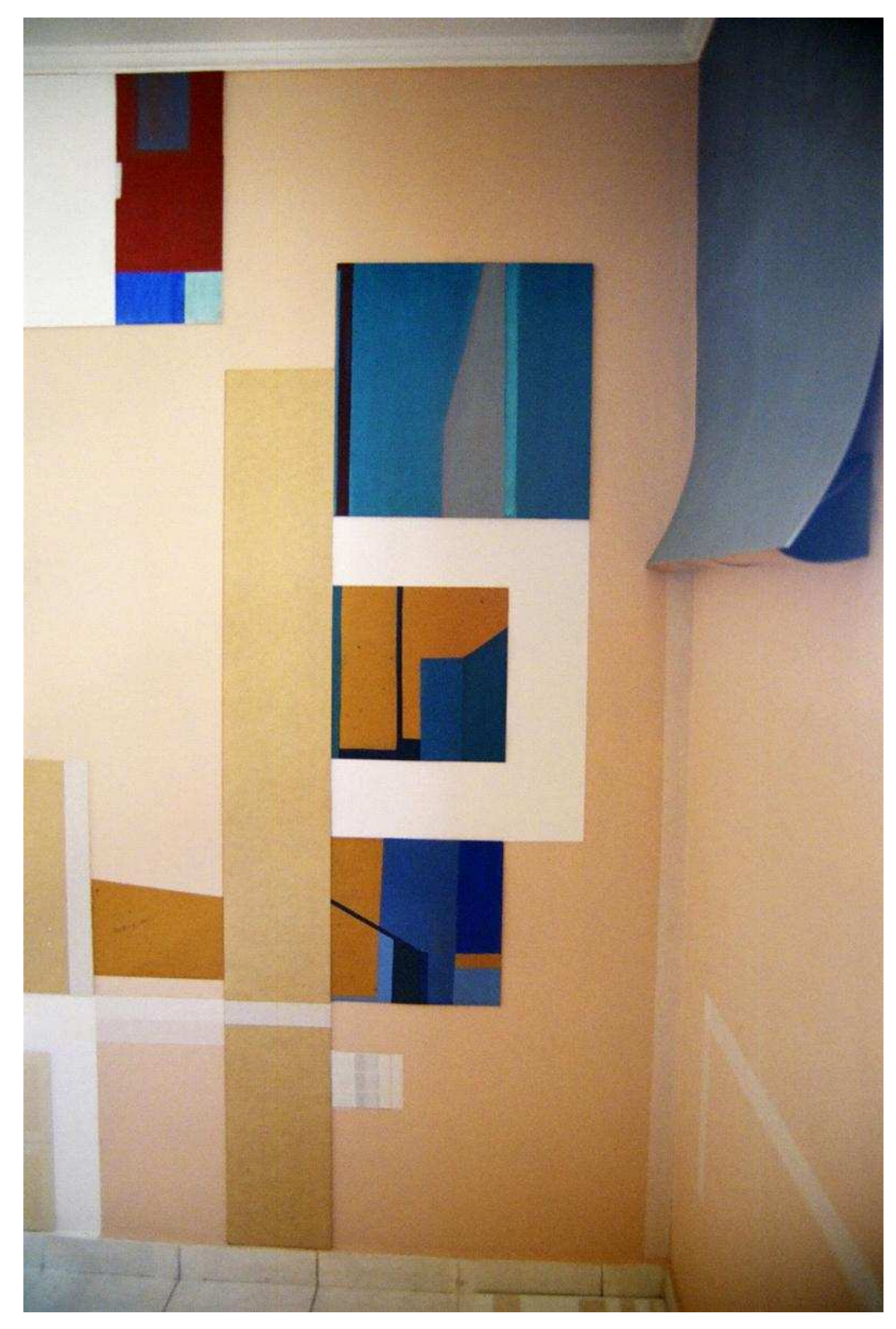




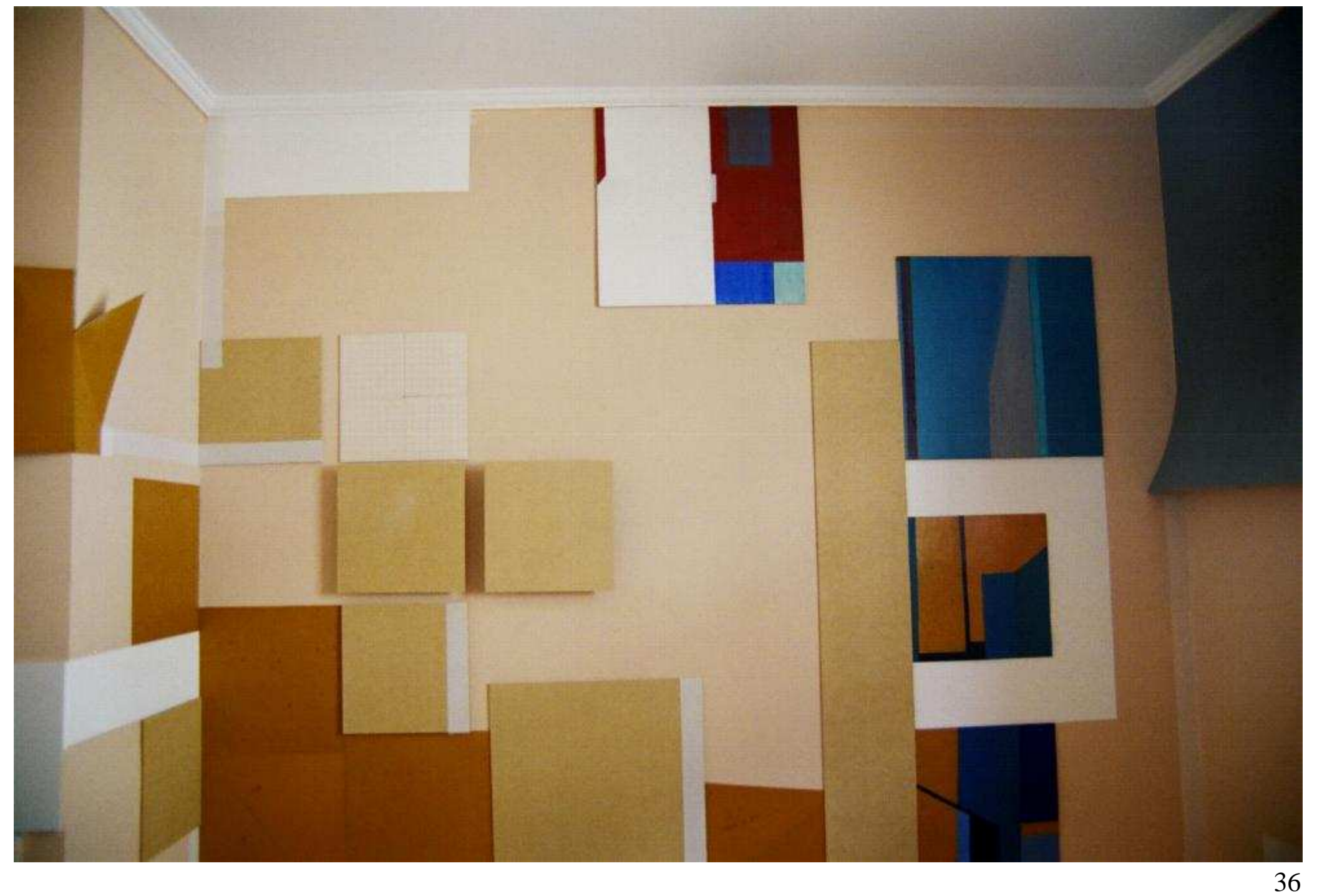




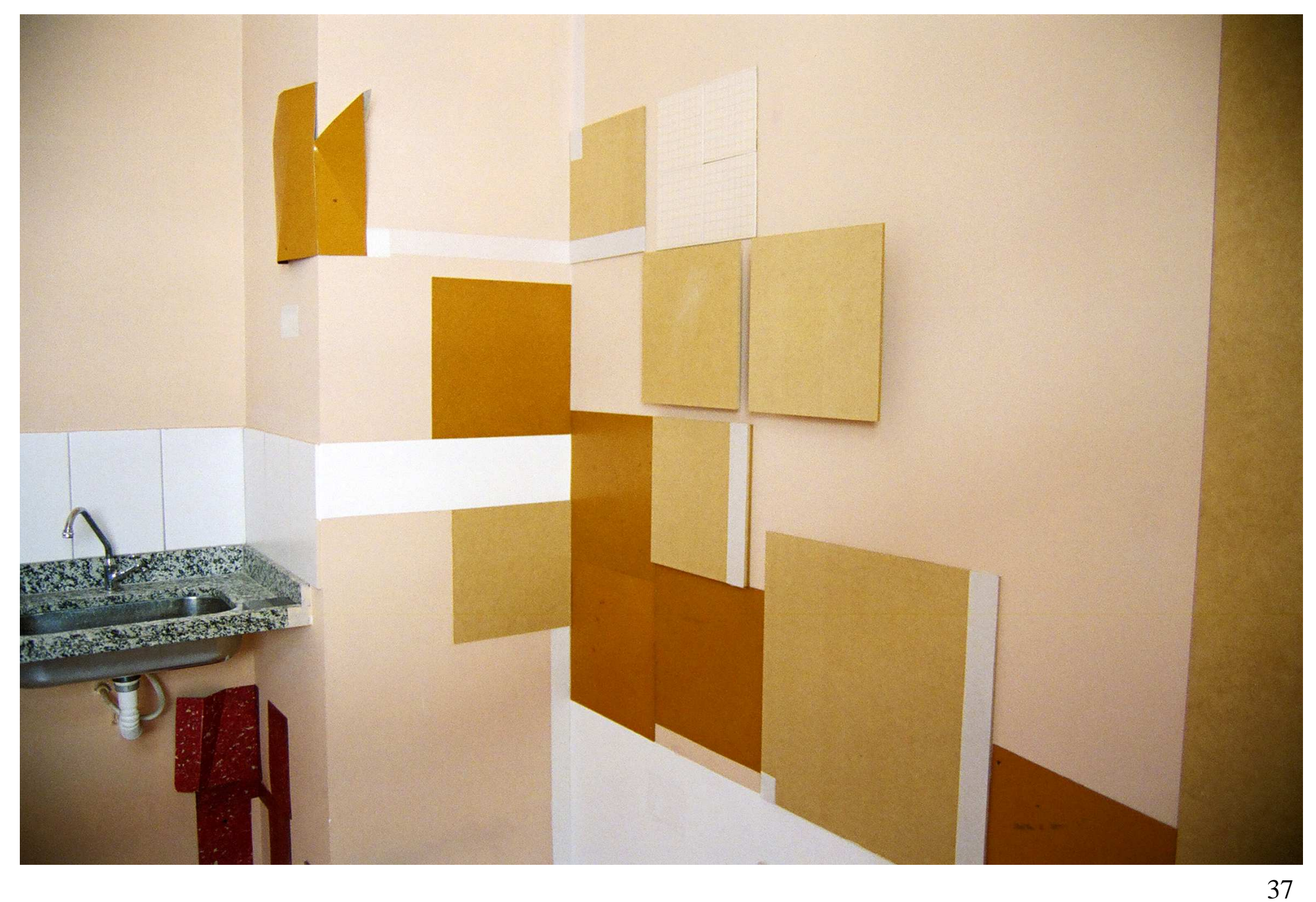




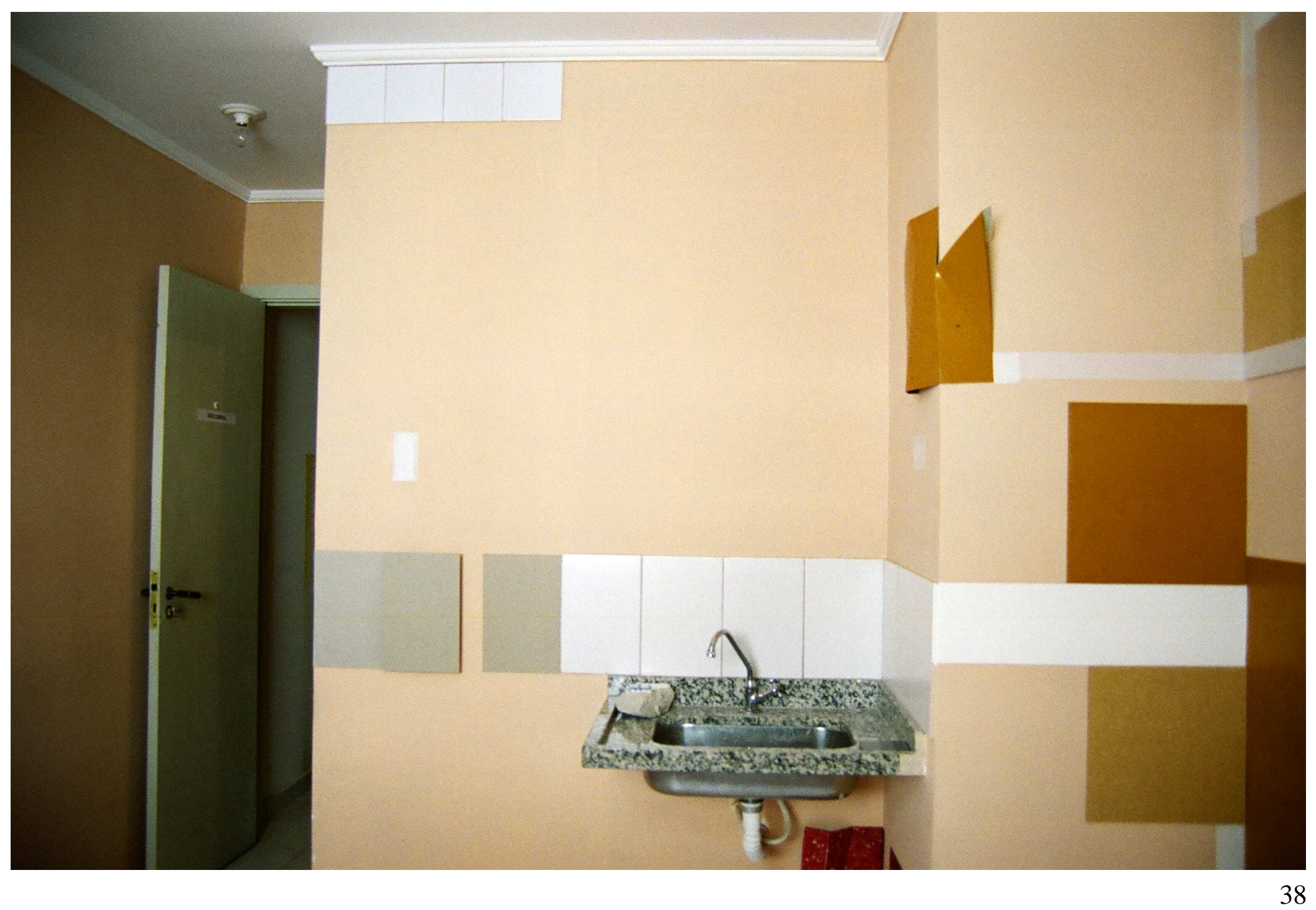


O trabalho criou uma imprecisão entre suporte e matéria da pintura, sendo este o próprio espaço urbano: "Tanto quanto o espaço arquitetônico, com o qual de resto se identifica, o espaço urbano tem os seus interiores. (...)"23. Muitas vezes, esses espaços são permeáveis, pelo uso de transparências de vidros, vidraças, comunicação por portas e janelas, espaços semi abertos/fechados ${ }^{24}$.

A ocupação do ateliê amarelo teve como estratégia estabelecer relações entre espaço interno e externo, por meio do uso dos materiais e das imagens da percepção e da memória. Assim como a do trajeto desenvolvido, por exemplo, partindo-se de outra localidade qualquer, para chegar ao ateliê, localizado no centro de São Paulo. 


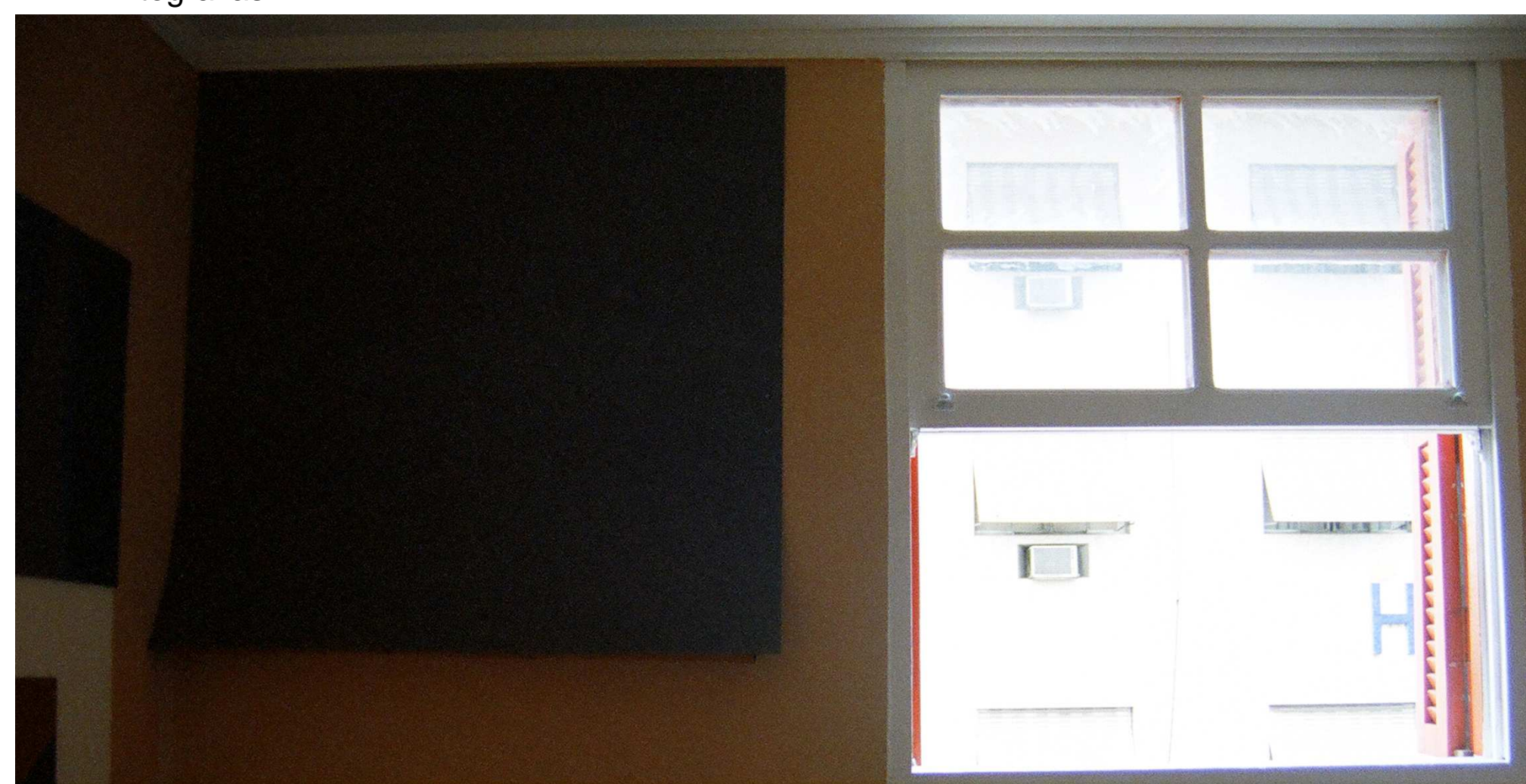




\section{Litografias}

Nas litografias, o desenho inicial é feito pelo depósito de material gorduroso em determinadas partes da pedra litográfica ${ }^{25}$, matriz a ser impressa e reproduzida posteriormente. Para construir a imagem na pedra, utilizei a goma arábica para proteger as áreas a não serem afetadas pela gordura e, como materiais gordurosos, o crayon litográfico e o tusche líquido a pincel, com diluição ora em terebintina, ora em água.

Cada pedra possui características particulares e pode se comportar de maneira a carregar-se demais de gordura ou a repeli-la um pouco. Nas pedras que utilizei, sendo uma de coloração cinza e, outra, amarelada, foi possível perceber que a cinza possibilitou a presença de meios-tons na impressão da gravação feita com o tusche misturado com água. A pedra amarelada reteve mais gordura e, durante a impressão, fechavam-se os meios-tons e mesmo as áreas preservadas da pedra. Por possuir essas características, essa pedra não aceitava bem gravações mais delicadas, foi preciso trabalhar com o tusche diluído em terebintina, solvente que torna-o mais gordo, o que revelou na impressão tons bastante escuros. Removi, algumas vezes, parte do excesso de gordura usando lixas, desenhando novamente, o que trouxe flexibilidade à gravação da matriz.

25 Por suas propriedades químicas, a pedra litográfica pode absorver água ou gordura com igual afinidade, sendo composta por aproximadamente 94 a 98 por cento de carbonato de cálcio e dióxido de cálcio, possuindo porcentagem mínima de impurezas. Garo Z. Antreasian, Clinton Adams. The tamarind book of litography: Art \& Techniques. Los Angeles: Tamarind Lithography Workshop, 1971, p. 304. 


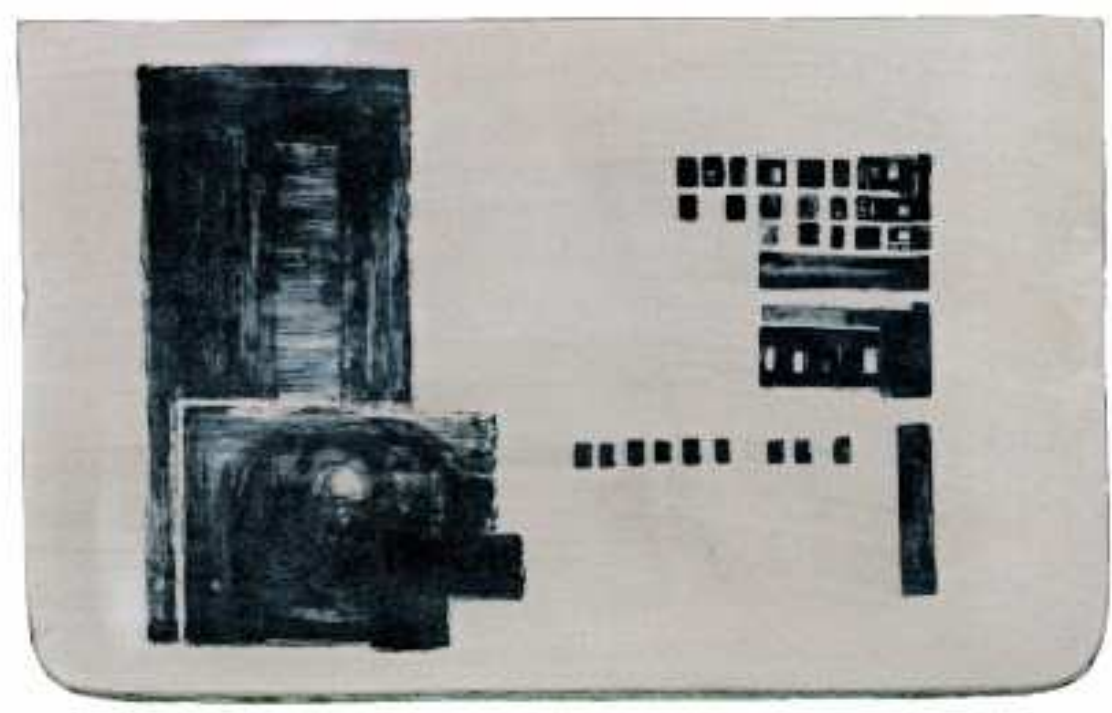




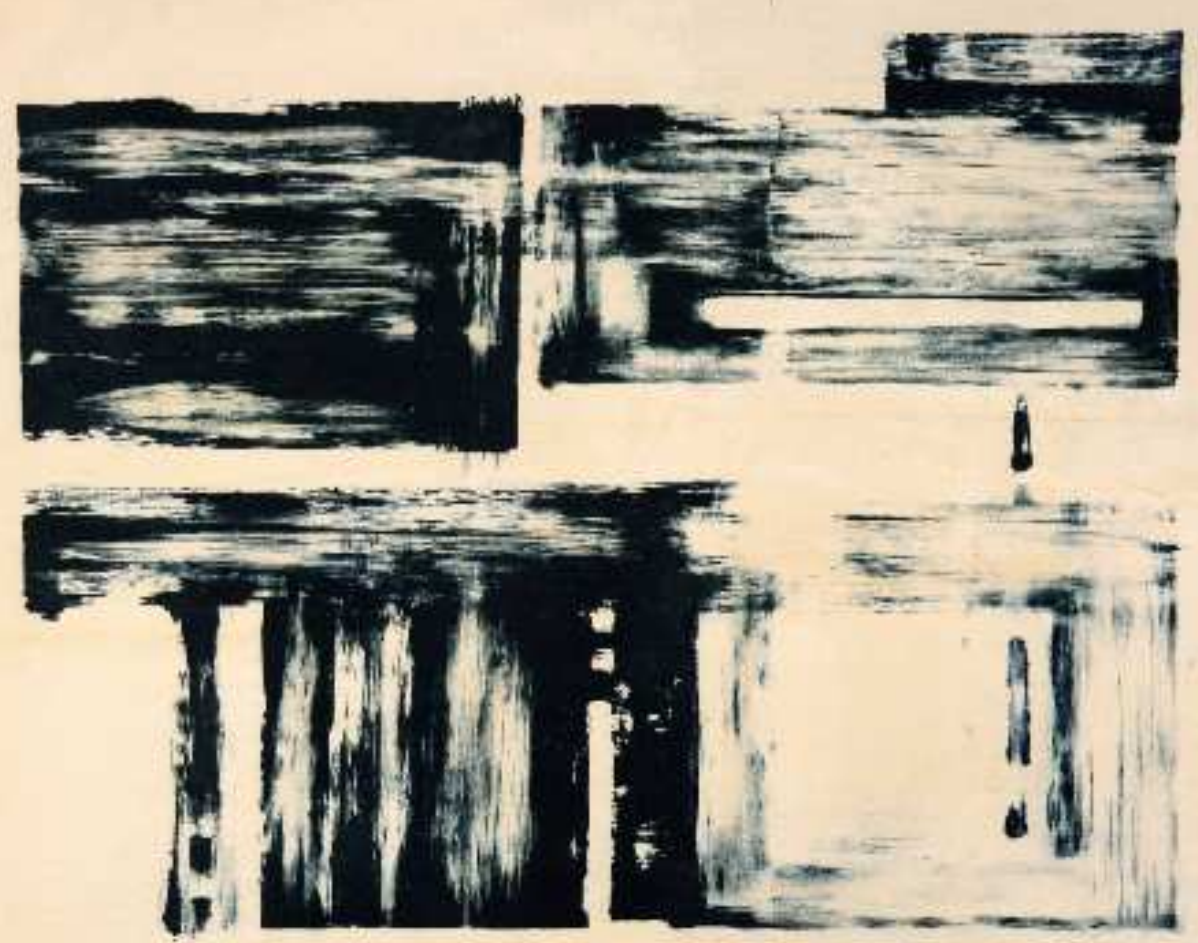


O processo de desfazer e refazer partes da imagem, retirando e depositando materiais, aproximou-se da maneira com que realizo as pinturas, com camadas de tinta que são depositadas sobre outras, escondendo ou se somando à camada inferior, como as veladuras encontradas na pintura.

No momento da impressão, a gravação inicial resulta invertida sobre o suporte, para o qual utilizei papel Hahnemüle $300 \mathrm{~g}$, sendo a pedra entintada com tinta off-set, a base de óleo. A partir dos testes de impressão, realizados no ateliê de litografia com a ajuda de técnicos, reproduzi imagens idênticas entre si, compondo uma tiragem. Optamos por criar também provas únicas, novas imagens a cada impressão, alternando o uso de cores, transparências e a sobreposição de imagens. Fazendo uso desses elementos, essas gravuras trouxeram questões relacionadas às pinturas que construo

Como um desdobramento das litografias, construí dois pequenos livros de artista, formados por corte e dobra da folha de papel e consequente fragmentação da imagem impressa. 

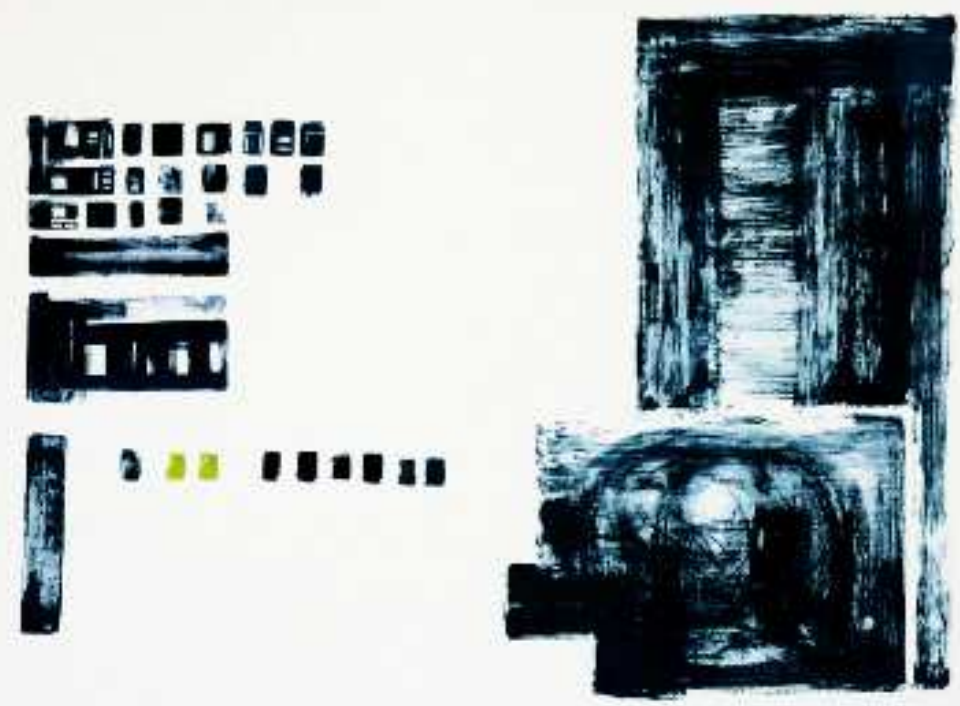


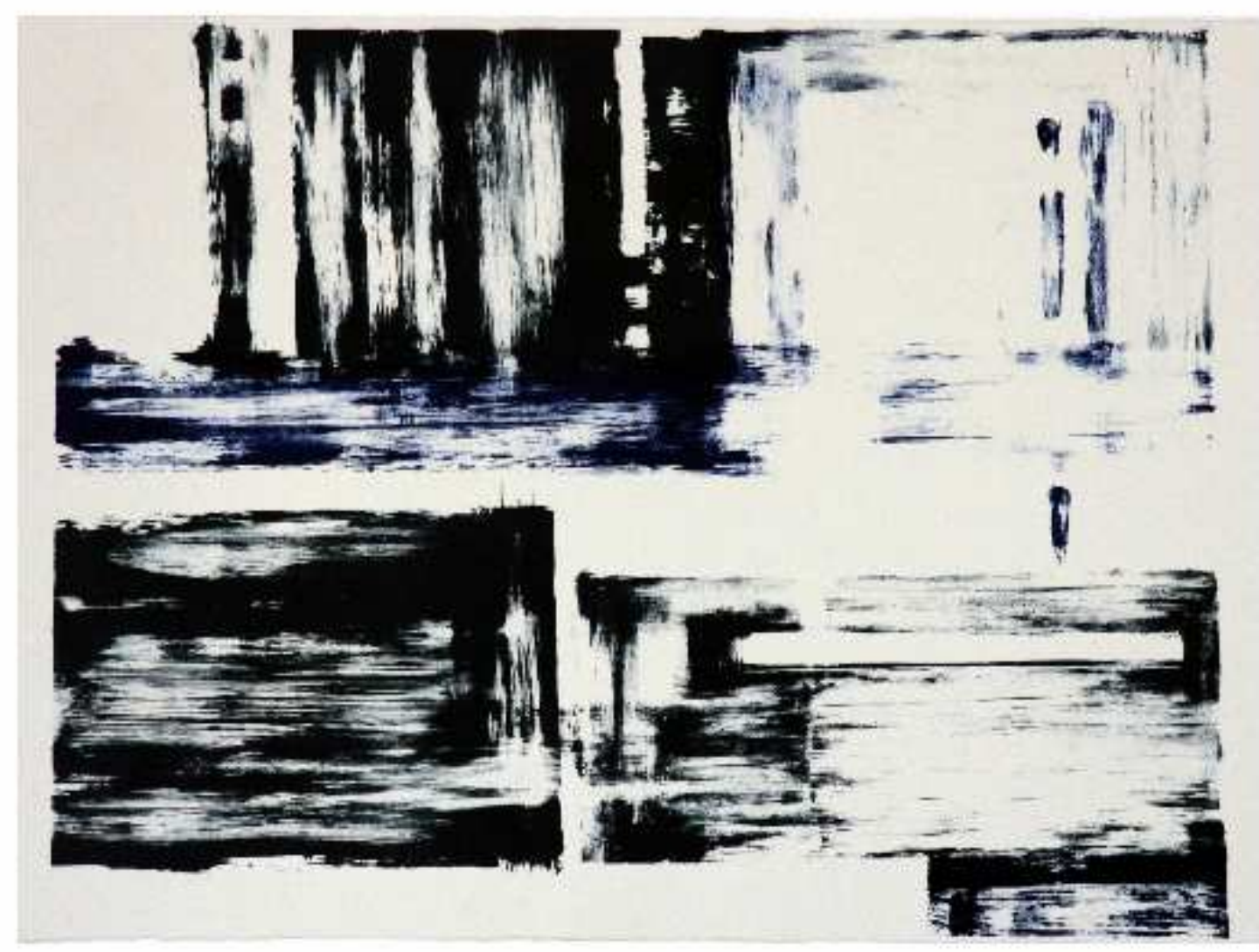




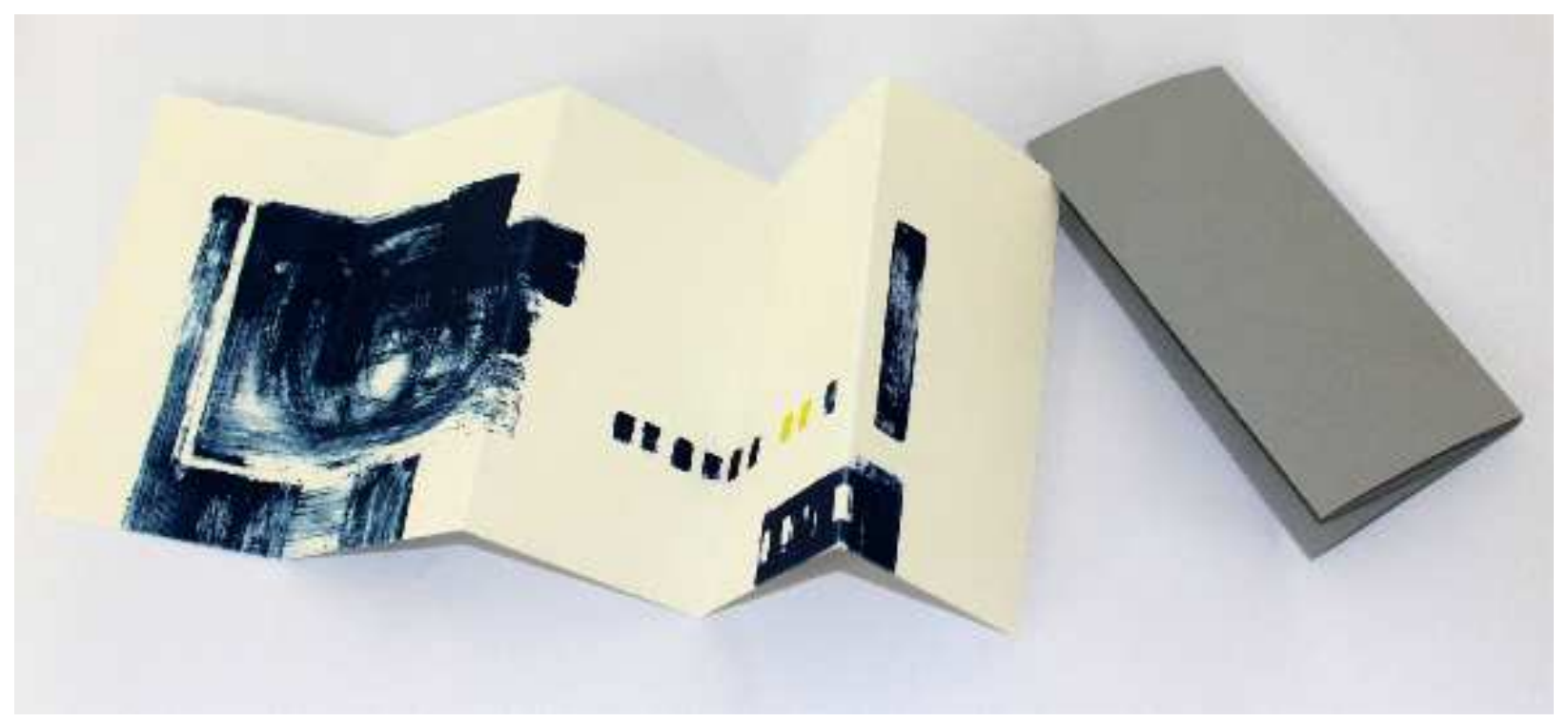


A poética26, a técnica e os materiais utilizados durante o fazer dos trabalhos envolvem questões relacionadas ao processo de desenvolvimento desta pesquisa.

A experiência do olhar e o contato com os materiais são anteriores ao momento em que existiu a intenção de desenvolvimento de uma determinada obra, continuando posteriormente.

Para que os trabalhos fossem construídos, foi preciso aprender a técnica necessária. Parte desta pode ser desenvolvida pelo autor durante a produção do trabalho ${ }^{27}$, pois os materiais possuem características próprias e isso pode ser percebido a partir de seu manuseio. Percebo que uma pincelada leve feita com o uso de pincel macio pode criar superfícies mais lisas. A maneira com que acontece a aderência da tinta a óleo numa superfície plastificada na qual a tinta não é absorvida, como a dos pisos industriais, dificulta a formação de uma película oleosa resistente. Os emborrachados oferecem pouca resistência ao encave e bastante flexibilidade quando dobrados. A fita crepe possui transparência e favorece a sobreposição de camadas, criando velaturas. Nas pedras litográficas, a diferença de granulação e a reação ao depósito de gordura podem ser notadas durante o procedimento de impressão da pedra no papel, não sendo aparentes no momento da gravação.

26 O termo poética está referido aqui como o estudo do fazer artístico desenvolvido por Paul Valéry, “(...)o reflexivo sucedendo ao espontâneo e vice-versa". Paul Valéry apud Julio Plaza. Arte/ciência: uma consciência. in: Revista ARS. São Paulo: O Departamento (CAPECA-USP), Ano $1 / \mathrm{n}^{\circ} 1 / 2003$, p. 46.

27 V. Luigi Pareyson. Os Problemas da estética. São Paulo: Martins Fontes, 1989 p. 30-32. 


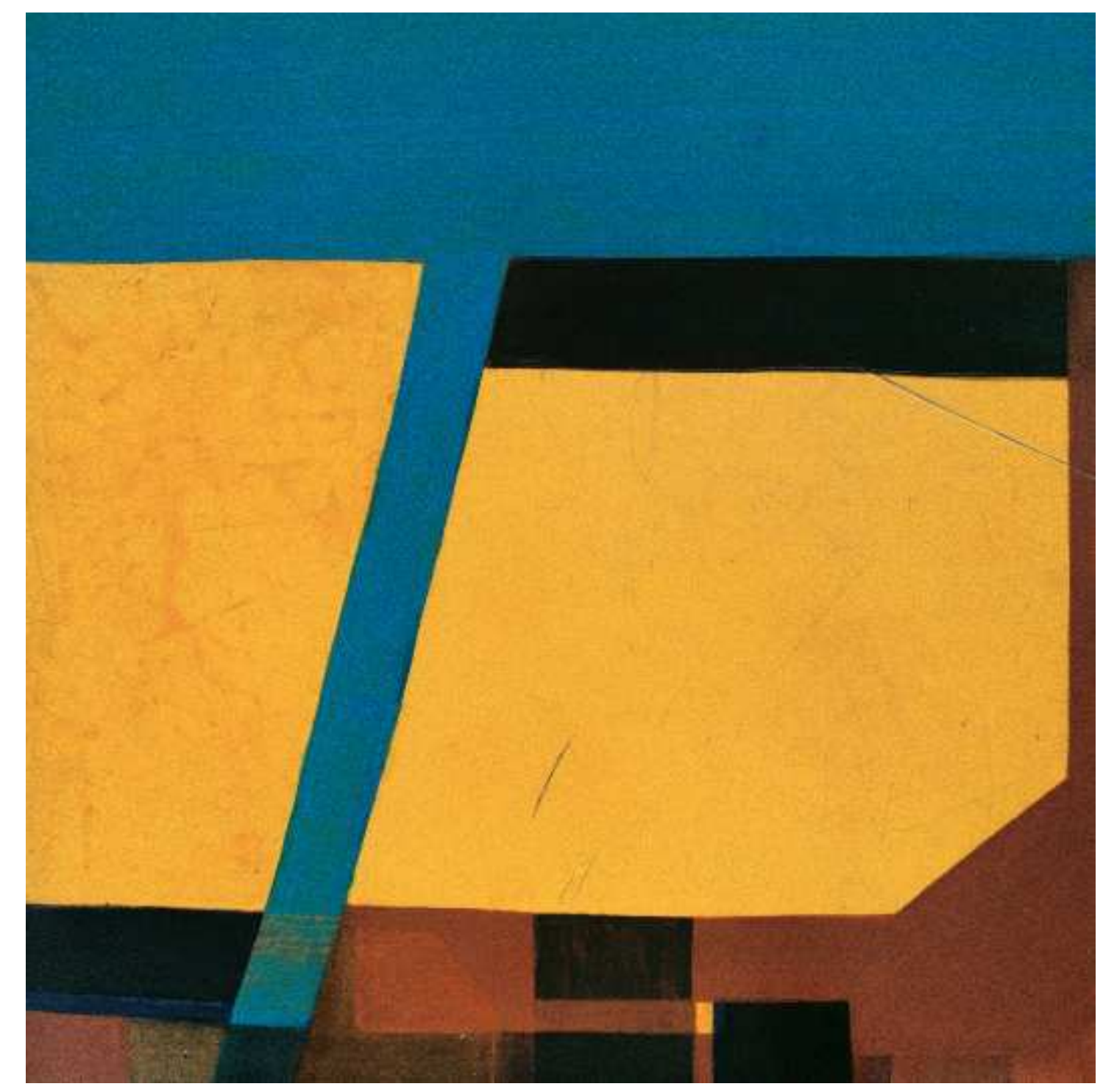


Ao situar e desenvolver a obra no ateliê, busco imagens que correspondem à rememoração de situações vivenciadas na cidade. Formas são intuídas pela relação entre o suporte e o instrumento utilizado para depositar ou retirar os materiais utilizados. As imagens criadas podem buscar associações com o entorno. Um objeto ou instrumento pode ser incorporado por estar presente no local de trabalho.

Algo semelhante pode ser dito sobre o uso da cor. Quando utilizo tintas que adquiro prontas, as cores precisam ser misturadas para alcançar um determinado contraste e expressividade. A tinta mais diluída proporciona maior transparência. Se aplicada em camadas sobrepostas, traz a sensação ótica de profundidade de campo. $O$ afastamento do pintor do trabalho faz com que seja alterada a percepção tida, por exemplo, do contraste cromático entre um azul e um branco. Dessa maneira, a mistura entre os pigmentos pode ser repensada e refeita. Materiais industriais, como os pisos, possuem uma cor determinada a partir da qual outras cores podem ser trabalhadas.

Qualidades de cor e forma possibilitam a construção do espaço no plano pictórico. 


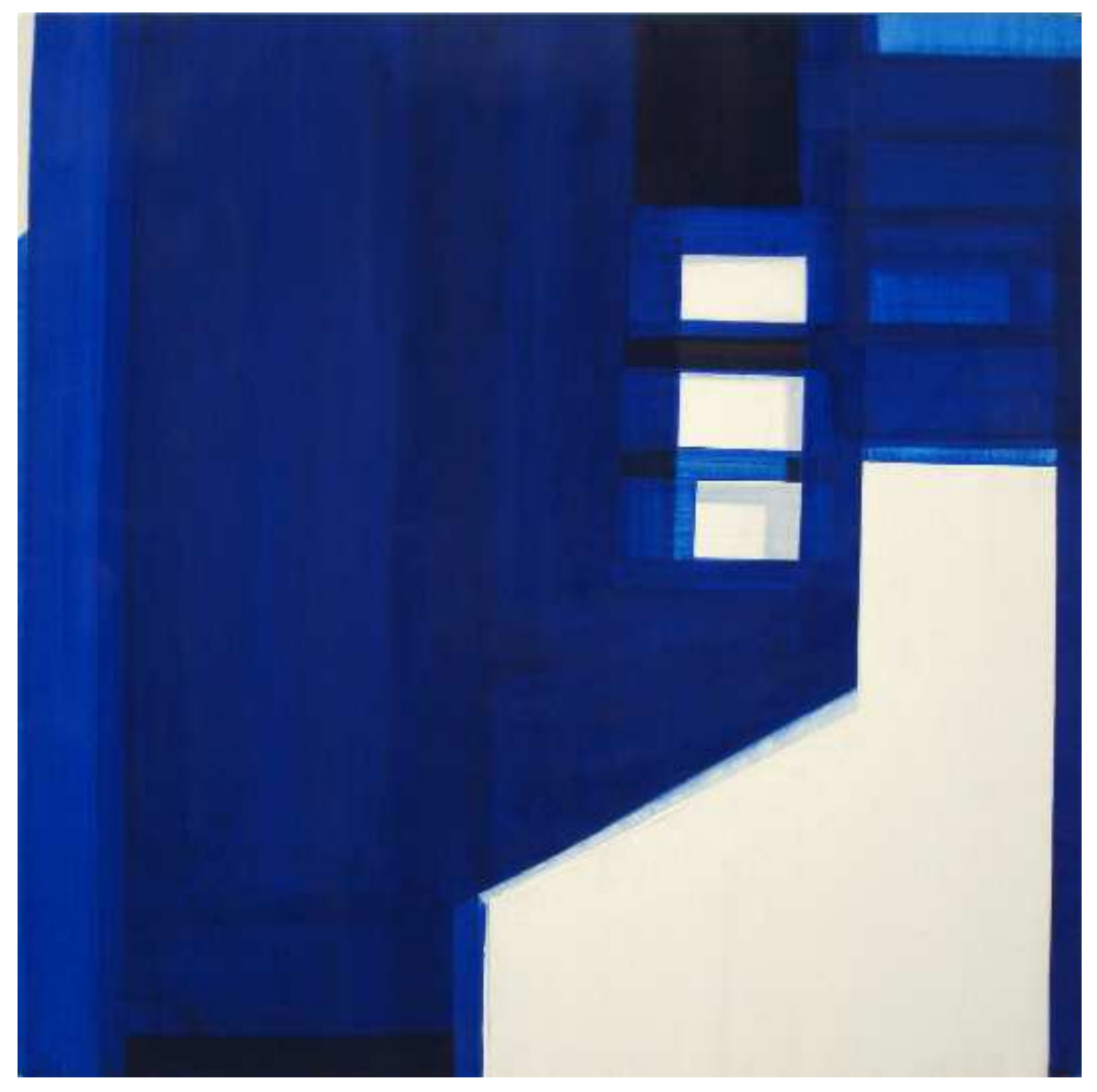




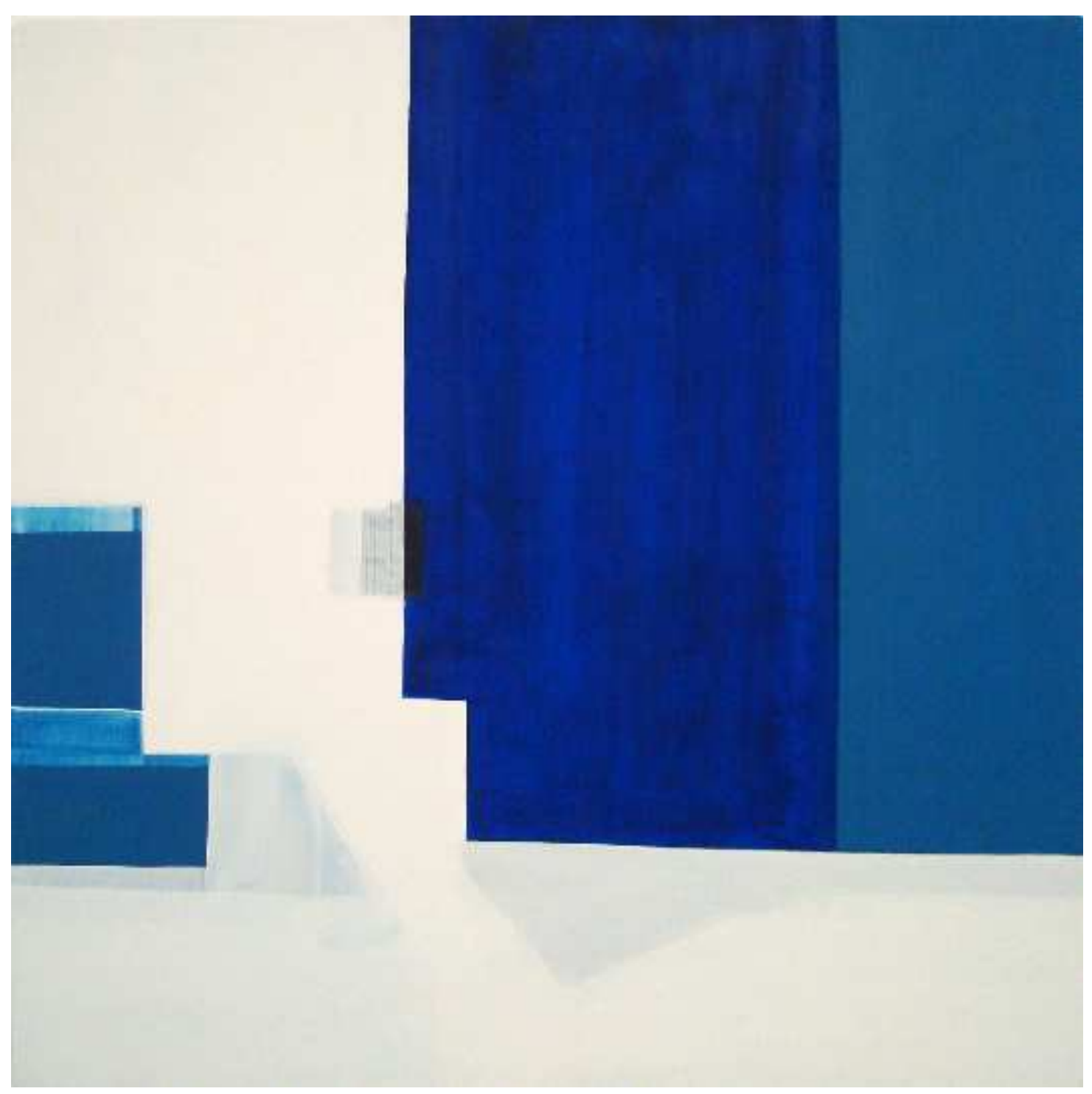


Aquilo que num primeiro momento é intuído, pode ser eleito como um processo consciente. Uma trama de tecido bastante aparente, como uma lona mais encorpada, pode ser tornada mais lisa pela aplicação de um fundo ou encoberta por grande acúmulo da tinta da pintura. O tecido, esticado no chassis, não oferece a mesma resistência ao manuseio que um suporte rígido, o qual possui superfície lisa e não recua a medida que é pressionado pelo pincel ou outro instrumento. A escolha por determinados materiais ou procedimentos determina a imagem obtida ao final do trabalho.

Ao se observar as pinturas percebe-se que camadas de tinta se sobrepõem, e às vezes se apagam. Nas paredes da sala ocupada no trabalho Mapa, camadas de materiais foram sobrepostas e acumuladas, incorporando de forma fragmentária o espaço interno, externo e o entorno daquela construção. Idéias e elementos que não possuíam uma relação direta podem ser aproximados. Significados podem ser formados para as obras com as quais se depara. ${ }^{28}$ As obras que fazem parte dessa pesquisa, com suas características próprias, poderiam levar aquele que olha de volta à cidade. 


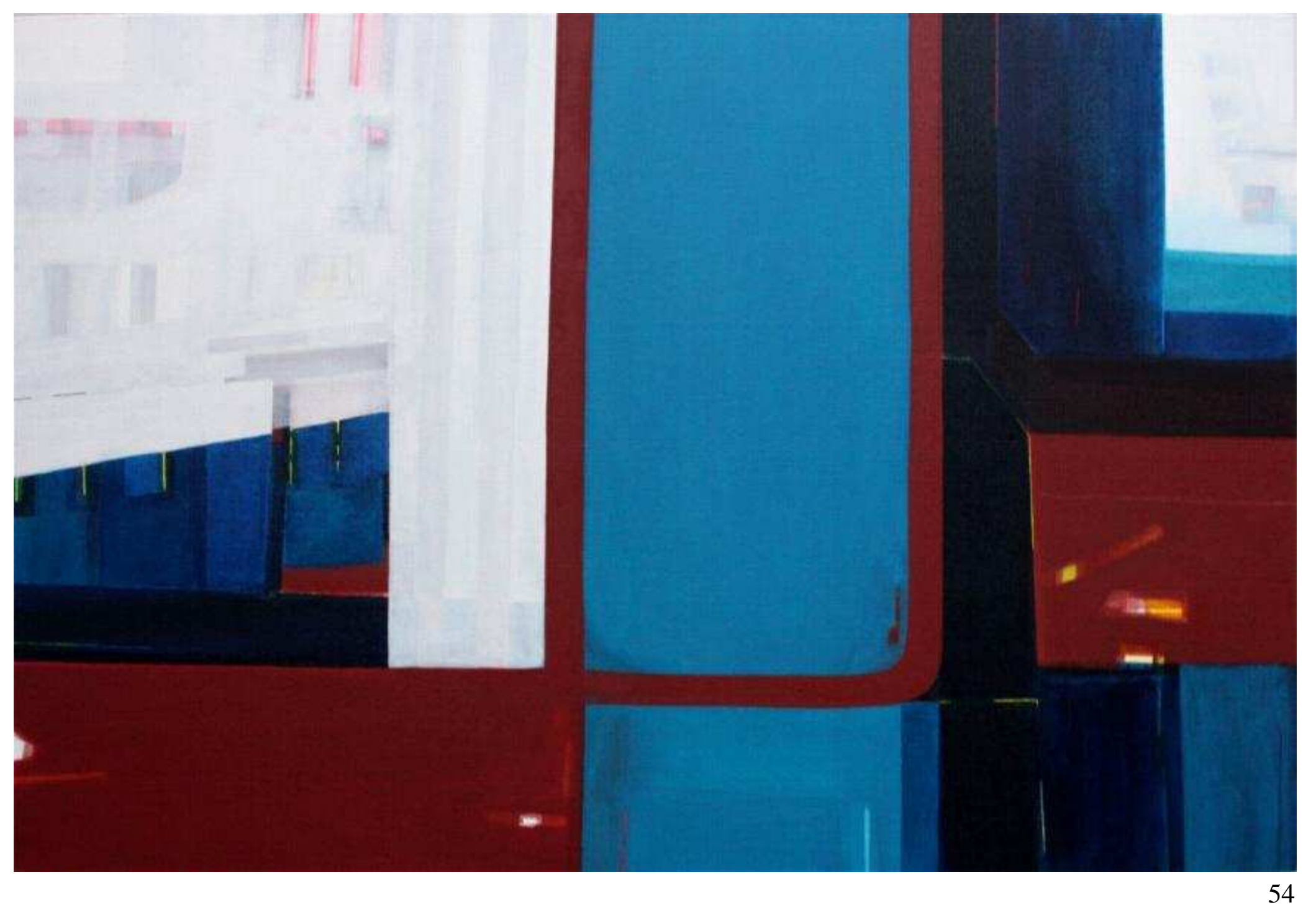




\section{Referências}

Busco me aproximar de alguns artistas e escritores pela relação que suas obras estabelecem com a cidade. Penso num recorte deste lugar que envolva a memória de vivenciar as construções urbanas. Pode haver uma similaridade mais diretamente visual, como nas referências a Alfredo Volpi e Piet Mondrian, ou mais ligada a percursos, como em Robert Rauschenberg e Kurt Schwitters; Jac Leirner e Marco Maggi trazem ainda referências materiais.

Mondrian busca a cidade que o rodeia ${ }^{29}$. Muitas de suas pinturas têm a composição determinada por elementos arquitetônicos e lembram a cidade de Nova York de 1960 ou a Paris dos anos 1920. Porém, as pinturas de Mondrian apresentam seus princípios compositivos, sem revelar semelhança com construções arquitetônicas ou ambientes específicos. Imaginava a cidade moderna por uma dimensão utópica, na qual buscava uma organização harmônica e dinâmica da vida urbana e da natureza, calcada nas atividades humanas, incluindo a arte, a arquitetura e a música.

Atento em especial à série Broadway Boogie-Woogie, feita pouco depois de ter se mudado para Nova lorque, na década de 1940. Em suas construções geométricas, estão presentes repetições de formas, quando cria um grande número de pequenos quadrados, ou retângulos e linhas retas, dentro da imagem, seriação que se relaciona com o formato do suporte utilizado. Cores se repetem, sendo, ainda, dimensão humana da pintura abstrata. São Paulo: Cosac \& Naify, 2001, pp. 7.
} 
limitadas ao grupo das cores primárias. Meyer Schapiro, ao referir-se à repetição de formas e cores na série Broadway Boogie-Woogie conclui que "Mondrian (...) nunca esteve tão livre e cheio de cores nem tão perto do espetáculo da cidade no duplo sentido que lhe conferem, de um lado, o aspecto arquitetônico como uma construção interminável de unidades regulares repetidas e, de outro, o caráter aleatório do perpétuo movimento de pessoas, tráfego e luzes piscando"30.

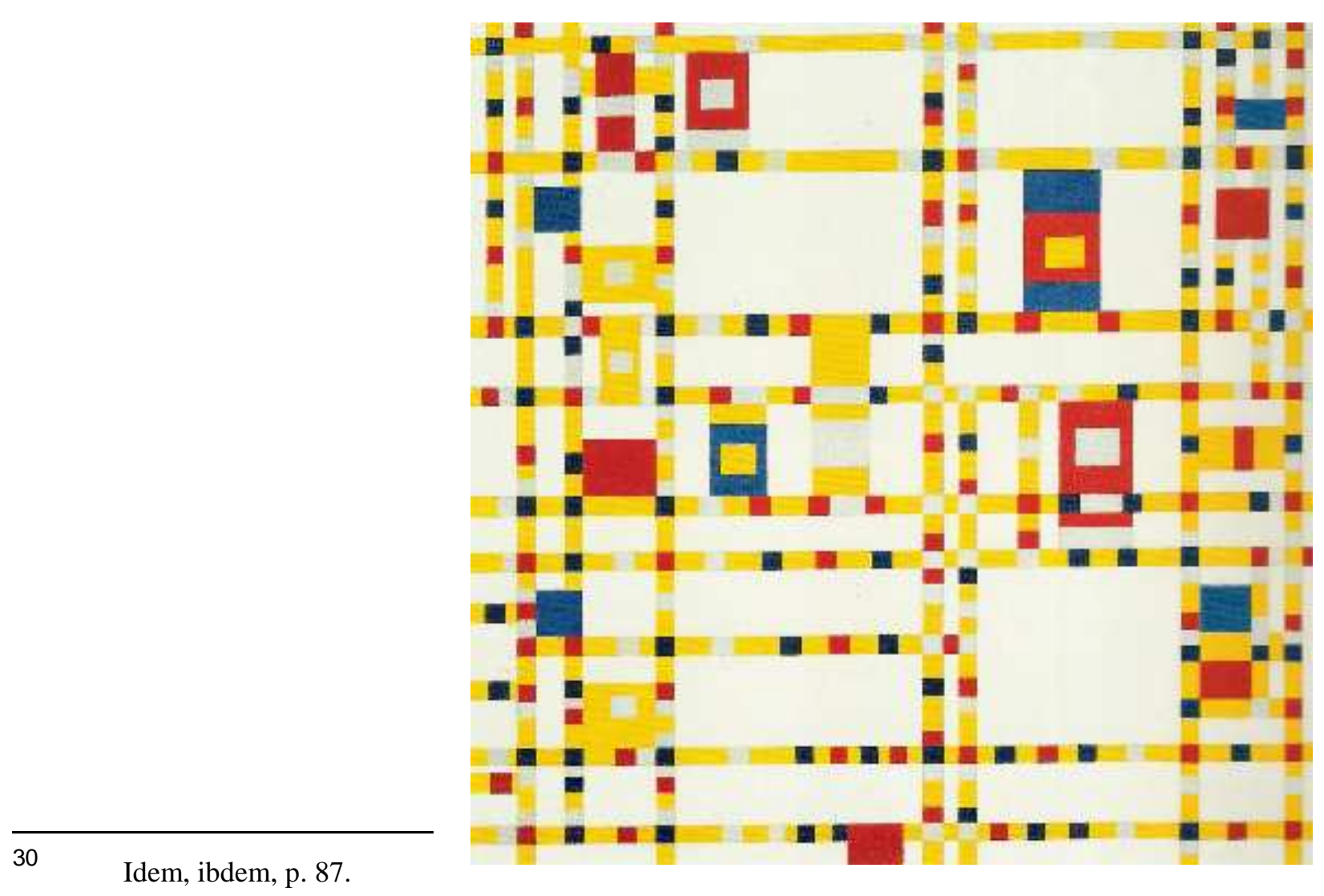


Podem ser referenciadas a estruturação do suporte, muitas vezes quadrado, e a visualidade desse conjunto de obras como presentes em meus trabalhos, porém, sem a mesma precisão geométrica e definição cromática que acompanham as obras de Mondrian. $O$ artista utiliza ainda o quadrado na posição de losango, criando outro tipo de organização da imagem, mantendo os eixos verticais e horizontais dentro do quadro. A articulação entre a dimensão utópica e as regras compositivas buscadas por ele são extremamente particulares e elaboradas, de maneira que as construções que desenvolvo se aproximam de outros parâmetros. Neste caso, a utilização de elementos geométricos, como verticalidade e horizontalidade e o cromatismo respondem tanto a questões relacionadas aos percursos desenvolvidos e às imagens reminiscentes e recombinadas da vivência na cidade, assim como a questões da fatura pictórica com determinados materiais, suportes e instrumentos. 
A ocupação Mapa, realizada dentro de uma sala de um prédio do Ateliê Amarelo, portanto um ambiente interno, relaciona questões da pintura com esse ambiente onde está inserida. Assim como o ateliê que Mondrian manteve em Paris, no qual o artista se apropria do espaço físico, objetos e mobiliário, bem como interferências da estrutura arquitetônica daquele lugar. Afasta, por vezes, os quadros, e os planos de cor sobre papel desenvolvidos para esse espaço, da superfície da parede e do chão, criando intervalos e aproximações entre as obras. Transforma o ateliê num desdobramento dos trabalhos, os quais por sua vez se somam àquele espaço. Se, neste sentido, aproximo ainda alguns de meus procedimentos, pretendo deixar claro que noutras proporções, sendo o ateliê vivenciado pelo artista durante mais tempo e de modo mais intenso e pessoal.

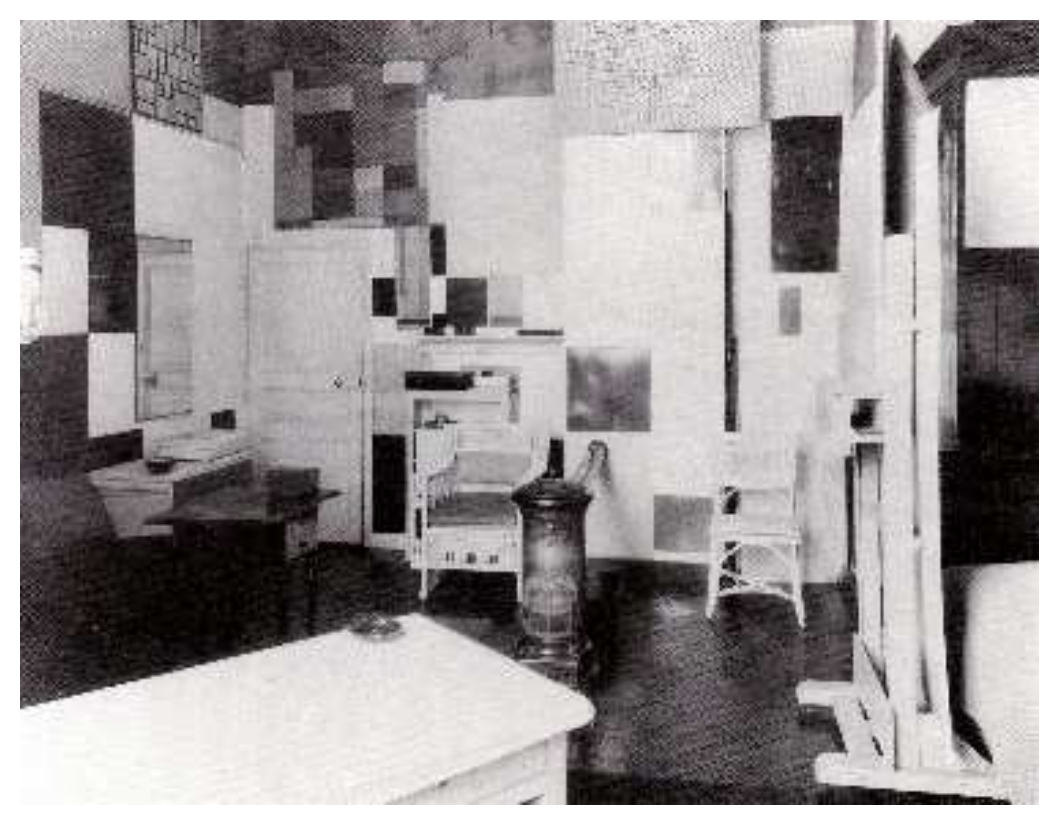


$\mathrm{Na}$ fase final de seu trabalho Alfredo Volpi busca a sintetização das formas. Sua obra está intrinsecamente relacionada ao fazer, descolada de uma obrigação mimética do assunto da pintura. Ao trabalhar com materiais e procedimentos mais artesanais, como a têmpera, e por não utilizar máscaras, para delimitar as áreas a serem pintadas, em seu procedimento técnico, suas pinceladas sugerem uma movimentação quase imperceptível dos objetos pictóricos, dada pelo contorno, que revela traços às vezes repetidos ou sutilmente imprecisos.

Nas pinturas que faço sobre as placas de MDF e as telas, uma aparente oscilação das formas pode sugerir uma imagem da memória, pelo esforço da rememoração de algo vivenciado, os contornos podem carecer de precisão.

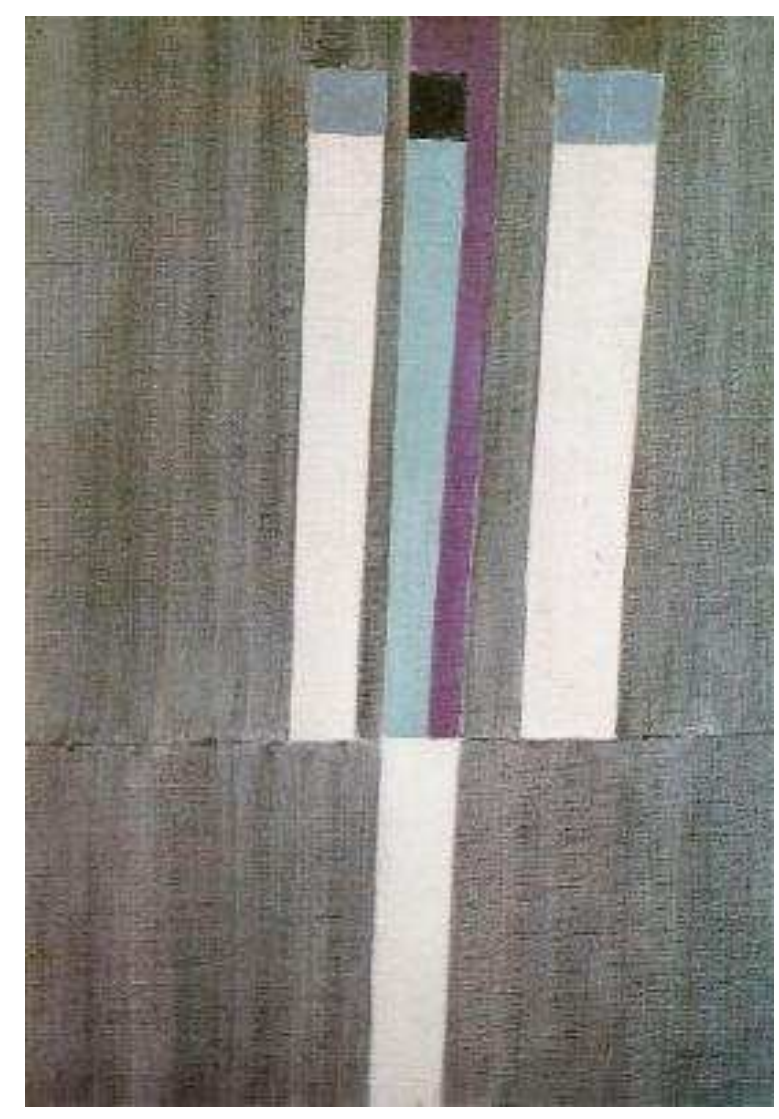


Jac Leirner em sua obra Hip Hop exibida em São Paulo no Centro Universitário Maria Antônia, em 2001, cria uma estrutura com a repetição de pequenos elementos coloridos, com pedaços de fita adesiva organizados numa linha horizontal na parede. Ela se apropria de um objeto cotidiano, a fita adesiva, que contém cor, para criar a forma, aplicada na sala expositiva, que se torna o suporte do trabalho. ${ }^{31}$ Estabelece um diálogo com Broadway Bougie-Woogie de Mondrian, pela repetição de pequenas unidades, pela referência ao ritmo, pelo cromatismo e pelo uso da linearidade e horizontalidade. Assim como com o ateliê de Mondrian, pela ocupação de todo o espaço circundante como parte da obra. A apropriação do espaço expositivo, tridimensional, a partir de unidades bidimensionais, a escolha e o uso dos materiais, são referências que aproximo de meus trabalhos.

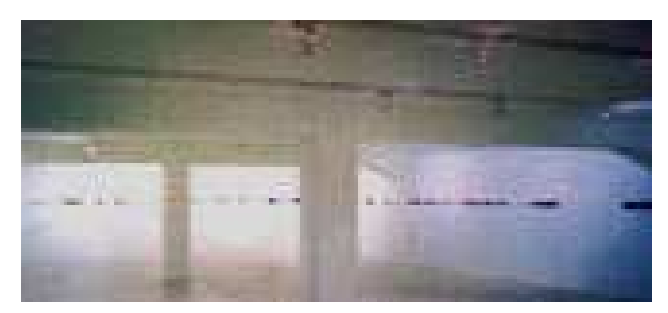

$31 \quad$ Mondrian já havia esboçado quadros com listas coloridas feitas com a nova fita-cola sobre a tela preparada em branco, como New York City II, 1942-44, no qual utiliza tinta a óleo e fita-cola adesiva sobre tela. John Milner. Mondrian. New York: Phaidon Press Limited, 1992. pp. 218. 
Segundo Adriano Pedrosa, características da arquitetura modernista, como linhas retas e superfícies planas, são também uma simplificação da visualidade, decorrente da movimentação acelerada do século XX. Contra o que propõe o trabalho de Marco Maggi, como uma desaceleração, resistência à passagem do tempo. Define que "Seu trabalho consiste em finos, precisos, delicados e sutis desenhos (às vezes feitos mesmo sem grafite o tinta) de intrincados padrões, em geral abstratos e geométricos, mas que remetem a arquiteturas, grades, teias, paisagens, mapas ou diagramas - reais, fabulosos ou idealizados". ${ }^{32}$

Sua obra Sliding ${ }^{33}, 2008$, faz referência ao enquadramento visual. Utiliza a estrutura de plástico que contorna o slide como moldura de pequenos desenhos feitos com ponta seca sobre papel alumínio. A partir da repetição de pequenos quadrados, remete a pequenos fragmentos de uma visualidade urbana percorrida. Utiliza, além do papel alumínio, folhas de papel sulfite brancas, empilhadas, formando instalações tridimensionais, que partem de elementos bidimensionais. Ambos os papéis, sulfite e alumínio, são de uso diário, e os suportes de papel alumínio dispensam a deposição de alguma matéria sobre eles, sendo manuseados de maneira que a cor e o desenho são parte do próprio material utilizado.

Encontro aproximações com os trabalhos que realizo sobre piso paviflex e decorflex, quando o suporte denomina parcialmente a cor e sua forma quadrada possibilita a repetição, assim como no uso que faço das placas de MDF, azulejos, fita crepe e outros pisos emborrachados, sendo materiais de uso cotidiano. 

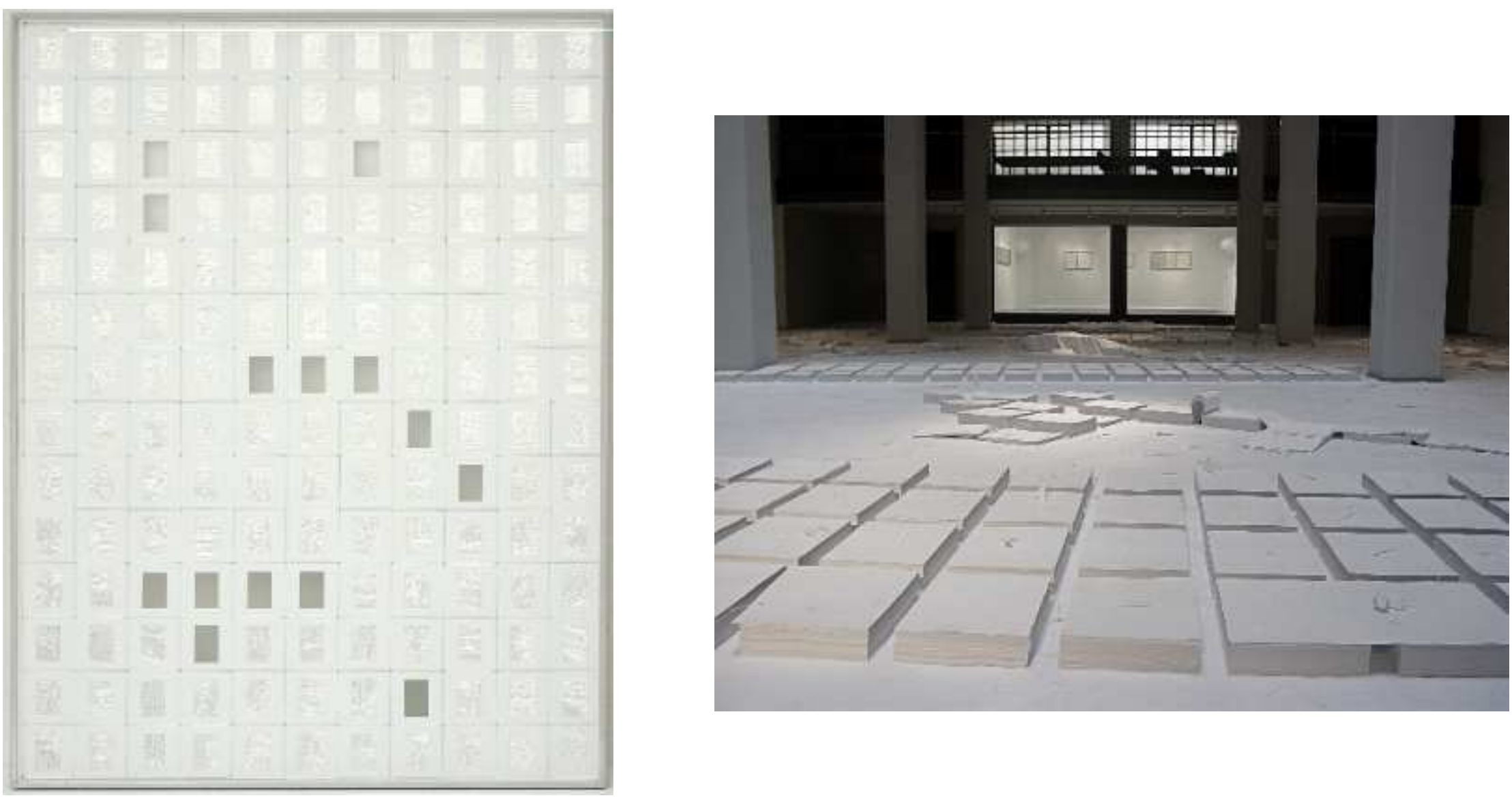
Significativo quanto à maneira de deslocar materiais e objetos de uso cotidiano para o âmbito da arte, o trabalho de Robert Rauschenberg colocou-o numa posição vanguardista. Estes não foram procedimentos inaugurais, porém reelaborações das vanguardas do inicio do século $X X^{34}$

O período de transição entre o Expressionismo Abstrato e a Pop Art pode ser visto como uma mudança de paradigma na história da arte, que parte para a construção de imagens com novos significados que se afastam da expressão do indivíduo.

Rauschenberg é um artista importante na passagem entre esses dois movimentos pela maneira com que cria uma relação dialética com o Expressionismo Abstrato, ao aparecerem em seus trabalhos características da Pop Art. Para ele a imagem, enquanto reflexão crítica, se distancia da personalidade, memória e desejos do artista, em contraposição à aproximação entre o artista e sua própria obra buscada pelos expressionistas abstratos.

Ao mesmo tempo em que surgem esses elementos de ruptura, existe a continuidade de pensamento de gerações anteriores. Uma maneira de ocupação do campo pictórico, quando a imagem se estende pela superfície da pintura, às vezes aos limites do suporte ${ }^{35}$, causa a impressão do campo ser um recorte de uma composição maior. $O$ all over, enquanto pensamento compositivo, pode também ser associado ao "conceito jornalístico de montagem", elaborado por Willi Bolle, no qual o "seu lay-out não

34 A apropriação de objetos na pintura havia sido feita por Picasso como uma possibilidade de incorporar a realidade à obra de arte ${ }_{35}^{\text {sem imitações }}$.

Como na relação entre figura e fundo utilizada por Pablo Picasso e Georges Braque durante o Cubismo, depois associada por Juan Miró e Paul Klee à poética de caráter abstrato, porém já caracterizando a busca de uma linguagem pessoal e expressiva, por Mondrian como característica do Neoplasticismo e então utilizada por Pollock e De Kooning, além de outros expressionistas abstratos. 
linear e, sim, espacial, sua disposição multidimensional da escrita, constituiu um enorme desafio para a cultura tradicional do livro. Benjamin evoca Stéphane Mallarmé, o primeiro a incorporar na poesia 'as tensões gráficas da publicidade', ou seja, 'o princípio de composição simultânea, constelacional'."36 Robert Rauschenberg explicita transformações ocorridas na pintura na década de 1950 em suas obras, que não simulam mais campos verticais, mas horizontais e opacos tipo flatbed. ${ }^{37}$.

Nas obras de Rauschenberg o espaço pictórico ganha gradativamente maior complexidade, primeiramente com as black paintings, em 1952, quando faz uso da colagem de pedaços de jornais, e, posteriormente, com as red paintings, 1952-53, nas quais colava espelhos, vidros e lâmpadas coloridas. Obras como Charlene e Rebus, trazem a colagem de objetos pessoais, como roupas usadas, e depois a inserção de objetos coletados pela cidade.

Rebus, 1955, é feito por Rauschenberg no final de um processo no qual usava cores indefinidas em suas pinturas, pois buscava o que chamou de pedestrian color, a mancha sem cores definidas que é percebida numa multidão, apesar das pessoas estarem usando roupas de várias cores diferentes.

$36 \quad$ Willi Bolle, op. cit., ed. cit., p. 91.

37 Termo utilizado por Leo Steinberg: "Tomo emprestado o termo flatbed à placa horizontal de um prelo - 'a horizntal bed on which a horizontal printing surface rests' (Webster) [uma placa horizontal sobre a qual se apóia uma superfície horizontal de impressão]”. A mudança de relação ao posicionamento dos eixos vertical e horizontal foi aludida numa atitude simbólica tomada por Rauschenberg quando pintou sua cama, travesseiro e colcha, fixando-a posteriormente na parede. "Do mesmo modo que um jornal, não dependem da correspondência com a posição humana de cima para baixo”. Leo Steinberg. Outros critérios: confrontos com a arte do século XX. São Paulo: Cosac Naify, 2008, pp. 116. 
Pensamento que pode ser associado ao conto "O homem da multidão", figura criada por Edgar Allan Poe, como "um desconhecido, que escolhe seu caminho de modo a se manter sempre no meio da multidão".

Em Charlene, 1954, Rauschenberg se desliga de imagens pessoais, fotografias de família e roupas usadas, para imagens impessoais do ambiente contemporâneo. Dessa maneira, suas obras perdem o sentido autobiográfico. Rauschenberg “(...) começa a pensar a si mesmo como um repórter. Uma testemunha ocular do centro de Manhattan"39. As figuras elaboradas por Charles Baudelaire e Edgar Allan Poe possuem descrição similar a esta. "O contraste entre Paris e Londres se condensa nas figuras do flâneur, um ocioso que se sente em casa nas passagens, e o Homem da Multidão, que percorre compulsivamente a cidade, 'errando pelo labirinto das mercadorias ${ }^{, 40}, 41$.

Rauschenberg diz que, "às vezes, é claro, os objetos simplesmente insistem em continuar sendo eles mesmos"42 - "in the gap between the two". ${ }^{43}$

Kurt Schwitters desenvolve colagens nas quais utiliza materiais como pedaços de papéis, de embalagens e pequenos objetos. As composições de algumas de suas pequenas colagens me interessam, como por exemplo em $M z$ 30,44, de 1930. Como sua estruturação predominantemente

38 Walter Benjamin, apud Willi Bolle, op. cit., ed. cit., p. 102.

39 ROBERT Rauschenberg: Man at work. Direção: Chris Granlund. BBC/ Guggenheim / RM Arts. Edição: Michael Poole. Narração: Sean Barrett. New York: 1997, 1 DVD (56 min.), COLOR.

$40 \quad$ Walter Benjamin, apud Willi Bolle, op. cit., ed. cit., p. 91.

$41 \quad$ Willi Bolle, op. cit., ed. cit., p. 91

42 ROBERT Rauschenberg: Man at work. Direção: Chris Granlund. BBC/ Guggenheim / RM Arts. Edição: Michael Poole. Narração: Sean Barrett. New York: 1997, 1 DVD (56 min.), COLOR.

43 ROBERT Rauschenberg: Man at work. Direção: Chris Granlund. BBC/ Guggenheim / RM Arts. Edição: Michael Poole. Narração: Sean Barrett. New York: 1997, 1 DVD (56 min.), COLOR. 
geométrica, a sobreposição ou justaposição de planos cromáticos e o uso da transparência. Amplia a colagem ao que denomina Merz, que abarca todas as manifestações artísticas. São consideradas as artes plásticas, artes aplicadas, literatura ou música, assim como a própria vida ou mesmo o que pareça banal: "Merz significa criar relações, de preferência entre todas as coisas do mundo"44.

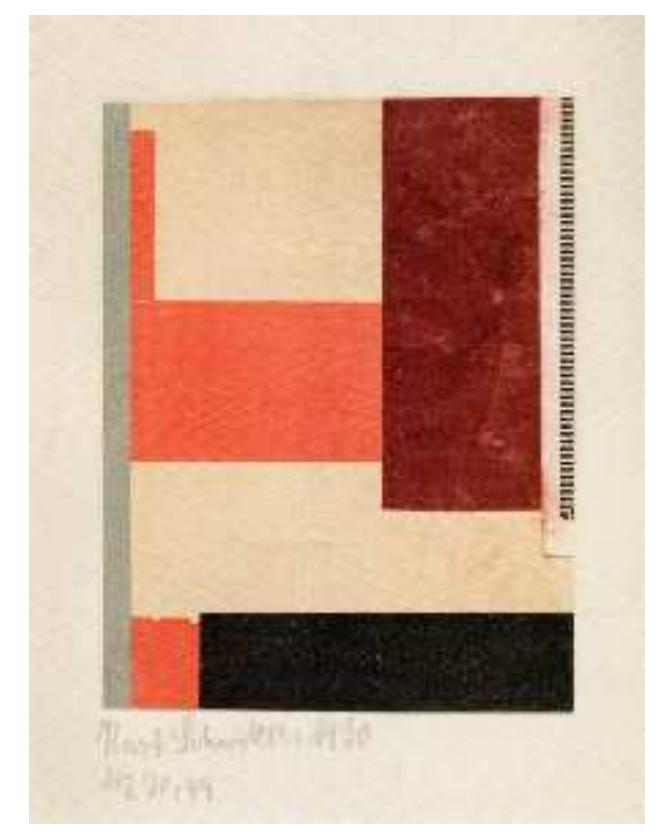

Kurt Schwitters. Merz, 1924. In: Kurt Schwitters 1887/1948 O artista Merz. São Paulo Pinacoteca do Estado, 2007; Curitiba: Museu Oscar Niemeyer, 2007, p.161. 
Constrói, num espaço tridimensional, uma instalação com todo o tipo de objetos e formas, relevos, esculturas, nichos e estrutura de iluminação. Merzbau não pode ser considerada pontualmente no tempo e no espaço pois suas diferentes configurações foram destruídas ou não acabadas, tendo sido parcialmente reproduzida a de Hannover na exposição realizada na Pinacoteca de Estado de São Paulo, em 2007. Merzbau era construída e retomada em suas diferentes residências, como se fosse uma única e mesma obra e ligava Schwiters a todos os seus amigos e família mesmo quando estava distante ou no exílio. Criava uma rede entre as pessoas, pois a partir dos objetos que utilizava, tanto de uso comum como os objetos de arte, deslocava e ampliava para o campo artístico todas as relações possíveis, entre os objetos e entre as pessoas, aproximando a arte do cotidiano.

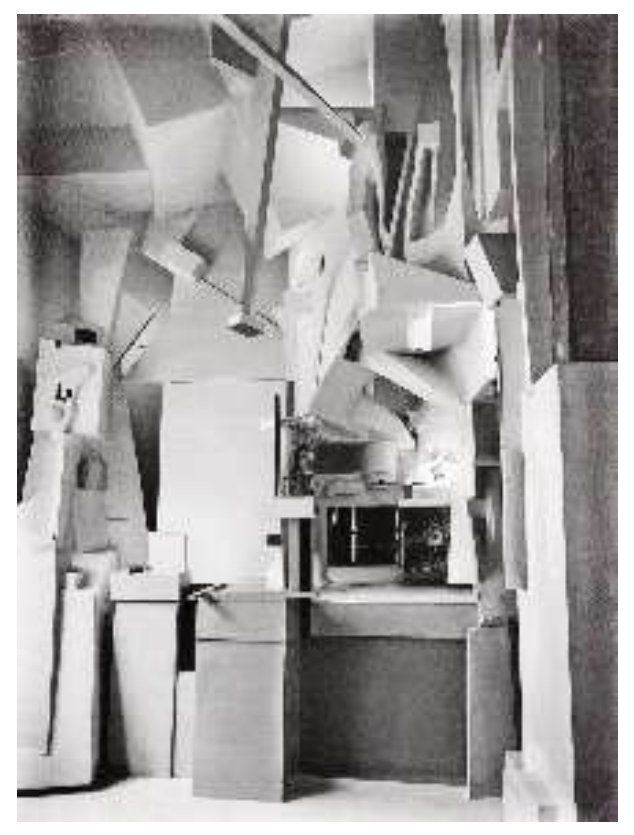


Acredito que me aproximo da obra de Robert Rauschenberg e de Kurt Schwitters pela relação estabelecida com os objetos enquanto matéria urbana e, ao mesmo tempo, material para construir um trabalho. Como quando utilizei o paviflex, com suas marcas e riscos do uso anterior, que foram pisos encontrados por acaso num ambiente de deslocamento cotidiano. As informações que contêm direcionaram parte das decisões que acontecerão posteriormente no ateliê. As pinturas sobre os suportes emborrachados e os rígidos são realizadas na posição horizontal e apresentadas na vertical, o que pode aproximá-las da idéia de flatbed.

Gostaria de relacionar Merzbau com o trabalho Mapa. A ocupação de um ambiente arquitetônico interno sendo considerado uma pintura, num ambiente urbano, diferentes em seu significado e configuração formal. No caso do Ateliê Amarelo, espaço coletivo, para o qual o artista era selecionado por meio de um edital, para trabalhar naquele espaço por um período médio de 6 meses. Mapa desenvolveu características mais próximas de uma estrutura bidimensional tendo sido os relevos criados a partir dos emborrachados, flexionados ou dobrados. As placas de MDF foram coladas umas sobre as outras ou sobre pequenos suportes de madeira que afastaram-nas da superfície da parede. A ocupação criou relações principalmente com o entorno daquele edifício e com a reminiscência dos deslocamentos cotidianos. 


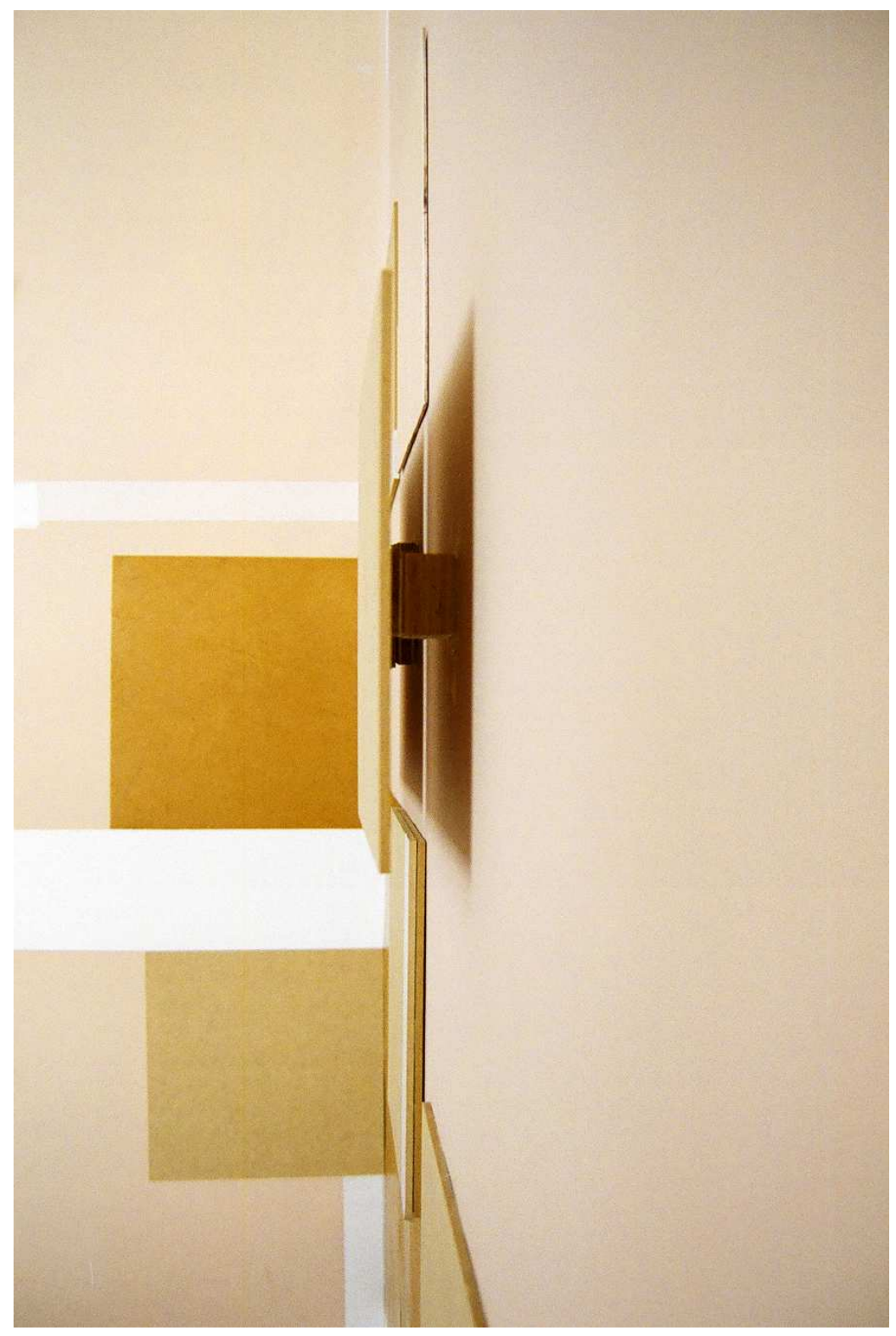




\section{Considerações finais}

Penso num mapeamento de percursos de diferentes pontos focais da cidade, visões aéreas, frontais, espaços internos e externos, fragmentos da percepção e relações da memória.

São estratégias do olhar que permitem identificar colagens e significações. 


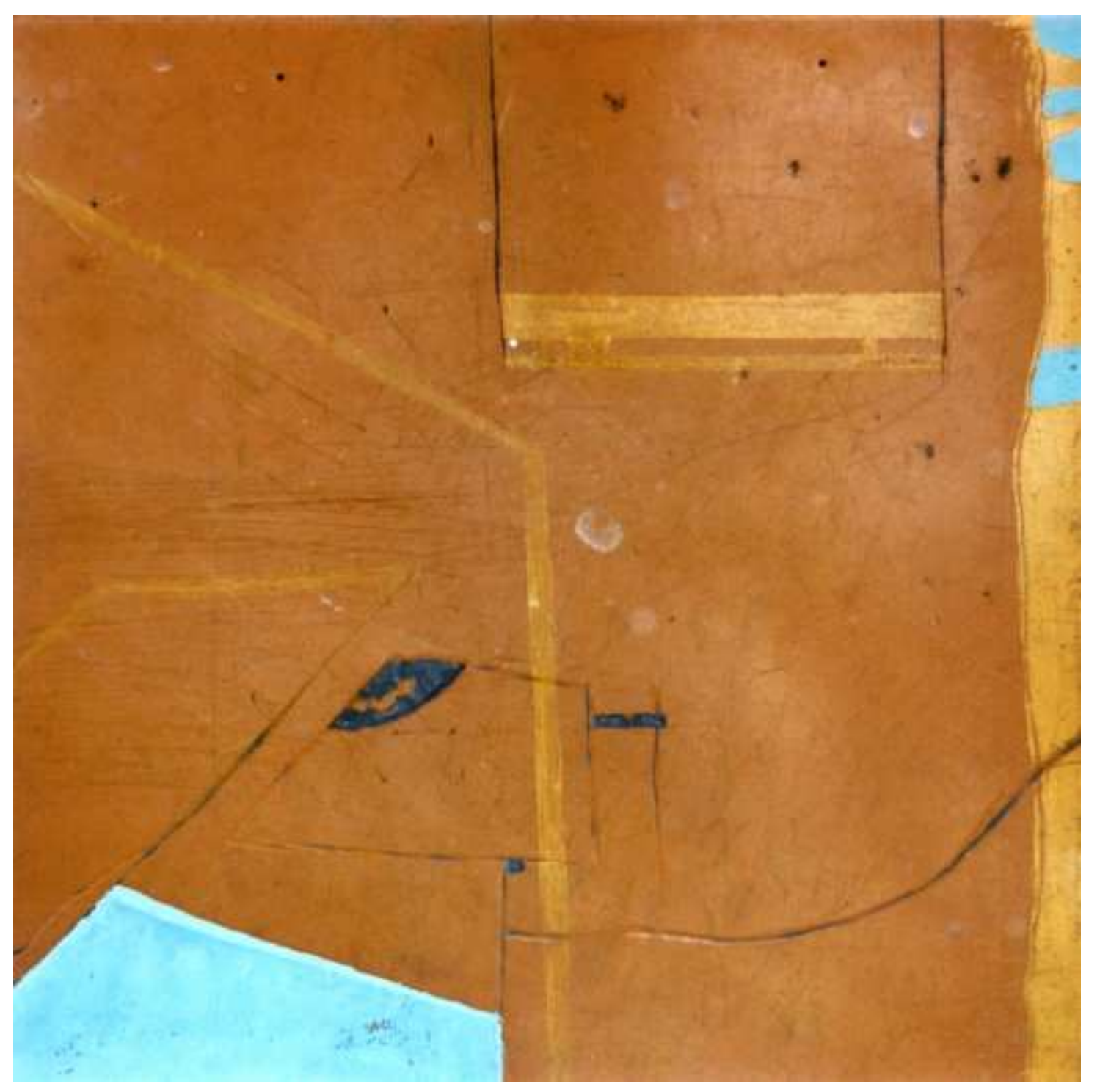


Durante a montagem das pinturas, é possível formar composições maiores a partir de combinações variadas. Quando afixadas sobra uma parede branca, as pinturas sem molduras que possuem áreas pintadas de branco trazem a impressão de continuar na passagem para o branco da parede.

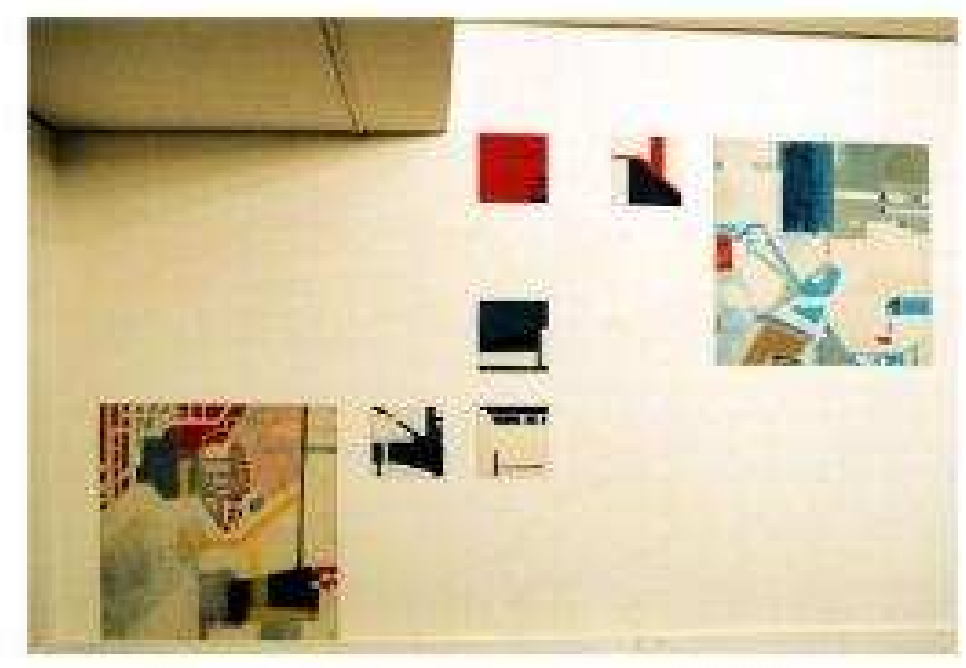


As dobras proporcionadas pelo livro de artista, decompõem e fragmentam as imagens litográficas, unindo-as de maneiras diferentes posteriormente.

$\mathrm{Na}$ ocupação Mapa, diferentes materiais foram somados à estrutura da sala. Imagens do entorno, assim como materiais utilizados em construções externas ao edifício, foram associados ao espaço interno. Para sua estruturação, os materiais foram colados com cola de contato sobre as paredes, o piso e o teto, assim como a fita adesiva, como uma colagem em grande escala. 


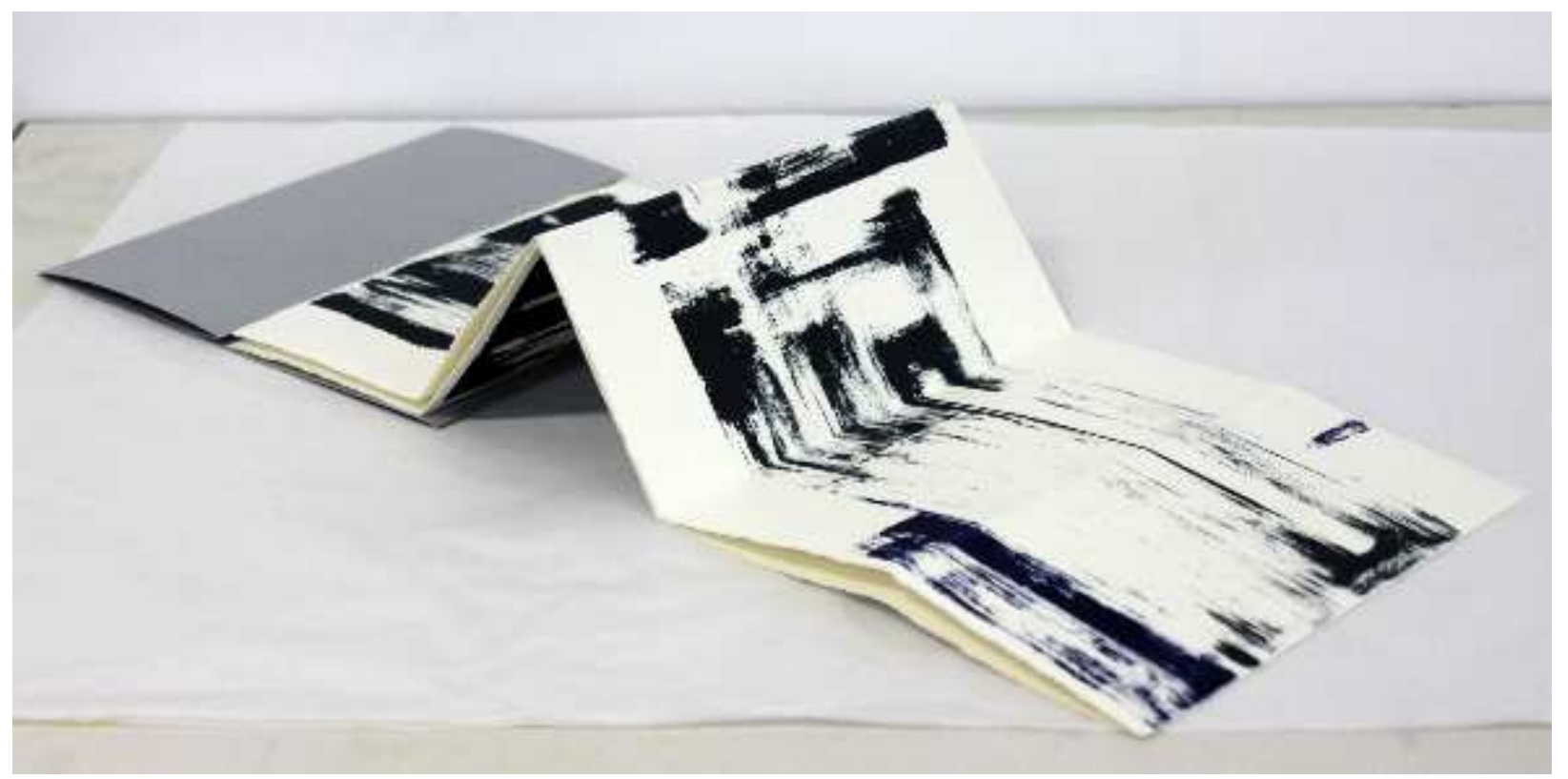




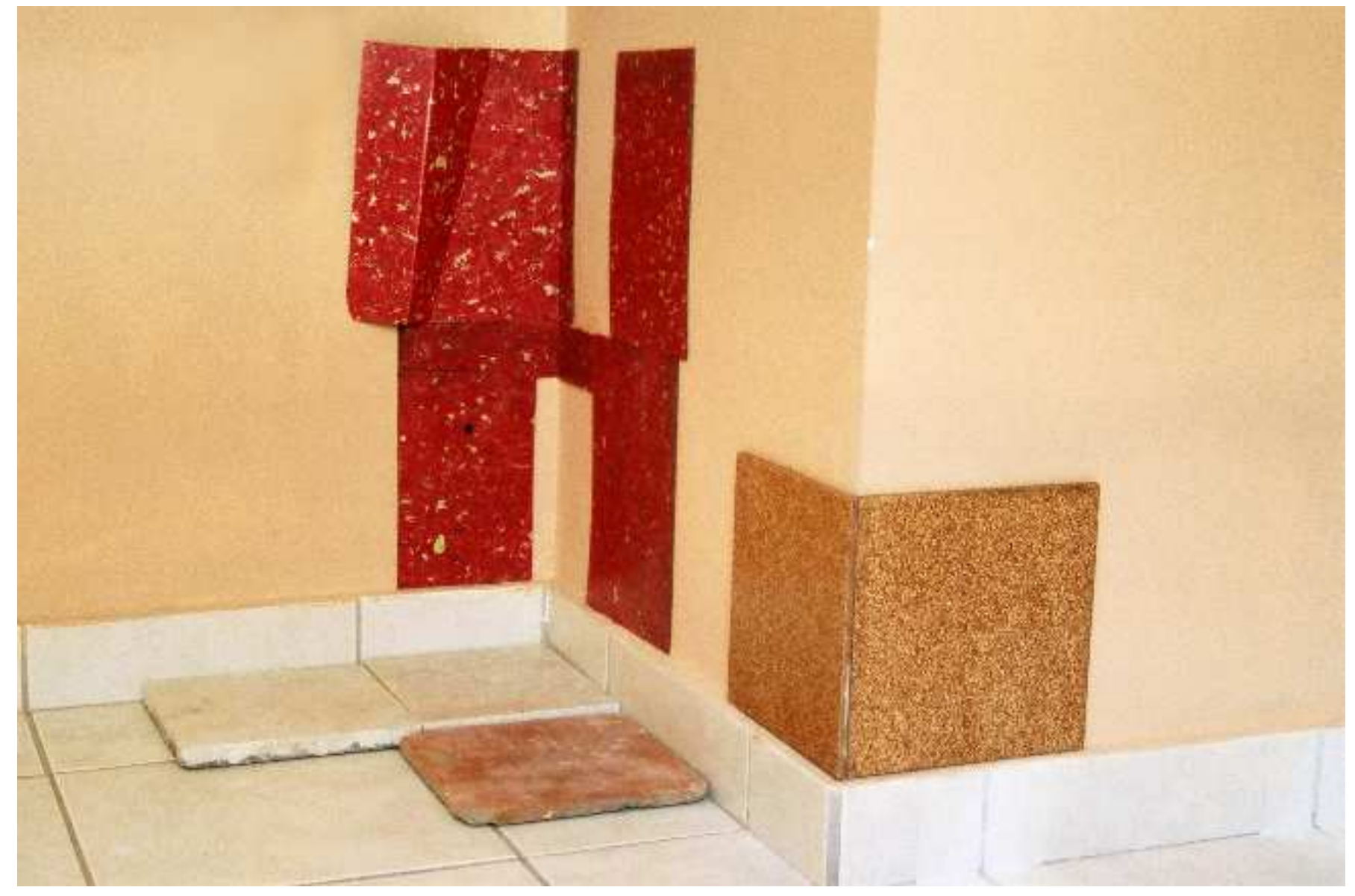


A arquitetura e o traçado urbanos estão em constante transformação. A memória pode assimilar as novas construções, sem a permanência do que estava antes. Ou não incorporar o novo, sendo percebido o que existia antes ao invés do que existe agora, em determinado lugar.

Aquele que vivencia a cidade a desconstrói através do olhar que não consegue conter toda a paisagem de uma só vez. Essa paisagem pode ser reconhecida por camadas de construções em frente a outras construções, como muros e paredes que encobrem parcialmente outras estruturas. Janelas podem criar enquadramentos da paisagem quando abertas, deixando aparente um recorte de uma imagem externa num ambiente interno. Janelas ou portas parcialmente fechadas e vãos determinados pelas estruturas permitem a existência de frestas que ocultam parcialmente a passagem da luz. A presença da transparência dos vidros possibilita ver partes de outros elementos e espaços e cria reflexos, o que pode modificar as cores dos objetos e construções, ou mesmo ocultá-los. A incidência da luz natural nas diversas horas do dia, assim como as luzes artificiais, mudam a coloração da paisagem. $O$ sujeito, que possui essa vivência, cria novas imagens na memória. Relaciona as coisas vistas e vivenciadas com sensações e outras imagens assimiladas anteriormente. Esse processo pode ser considerado uma colagem. 

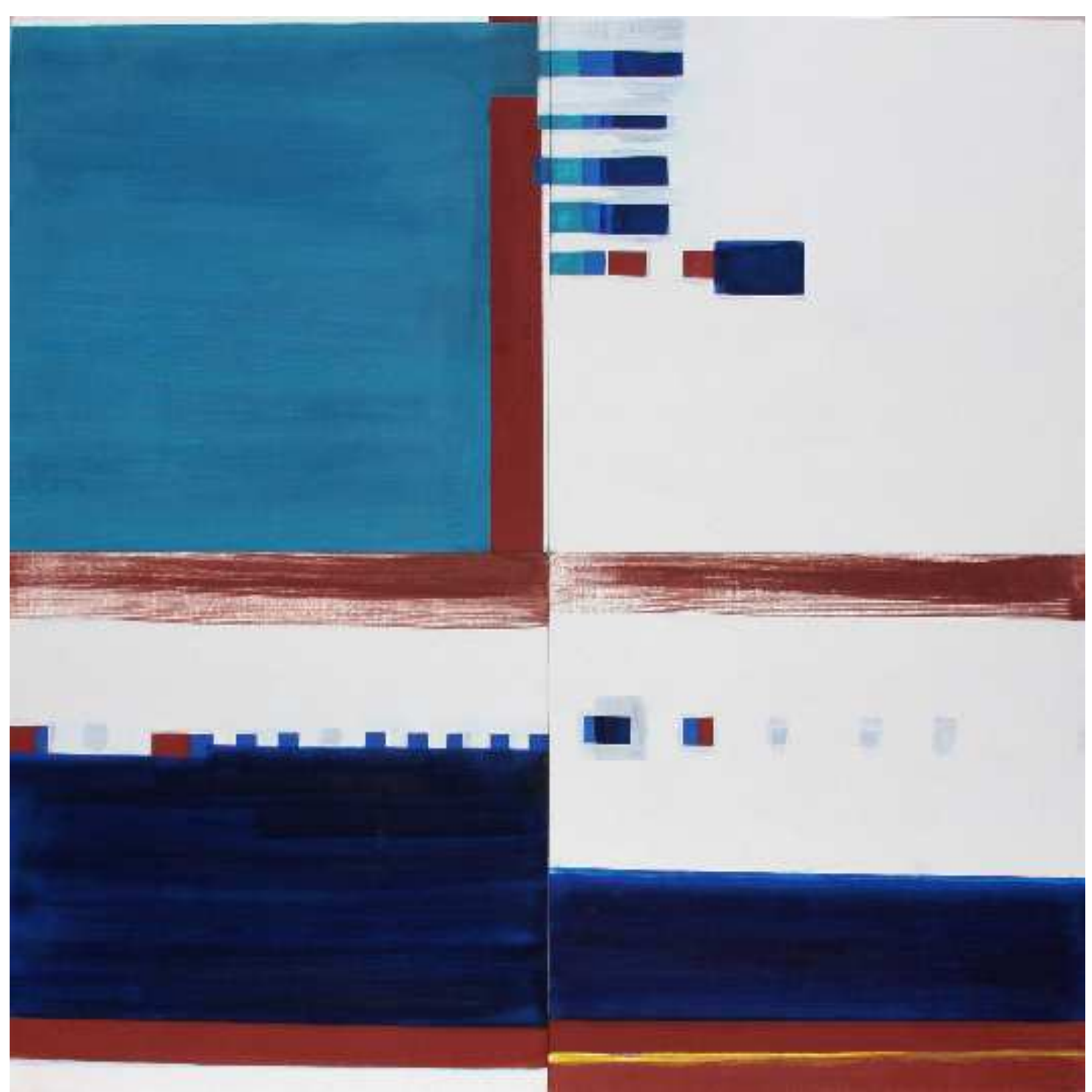
Um mapa mental pode ser como uma colagem na qual os fragmentos de imagens rememorados são unidos e criam um novo elemento, significado ou imagem. "(...) não como ela se encontra num mapa Pharus, mas tal como se inscreveu na memória de um de seus habitantes.. ${ }^{45}$ Nesse caso, uma única cidade, São Paulo, vivenciada por um tempo e que, ao mesmo tempo, deixa de sê-la. Torna-se reminiscente, nunca sendo a cidade inteira.

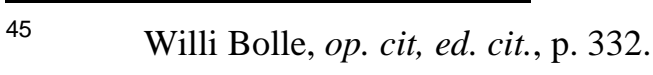




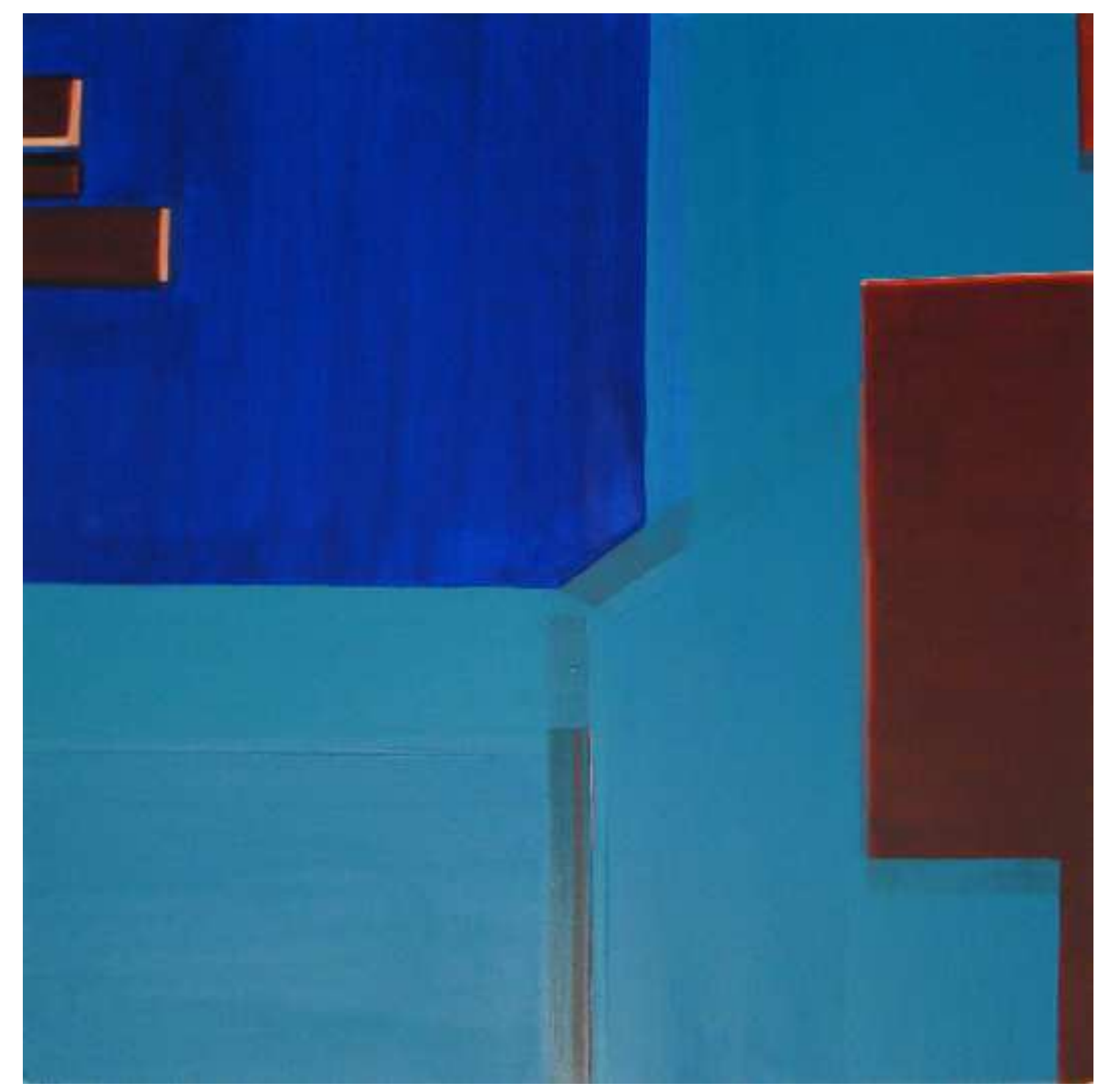




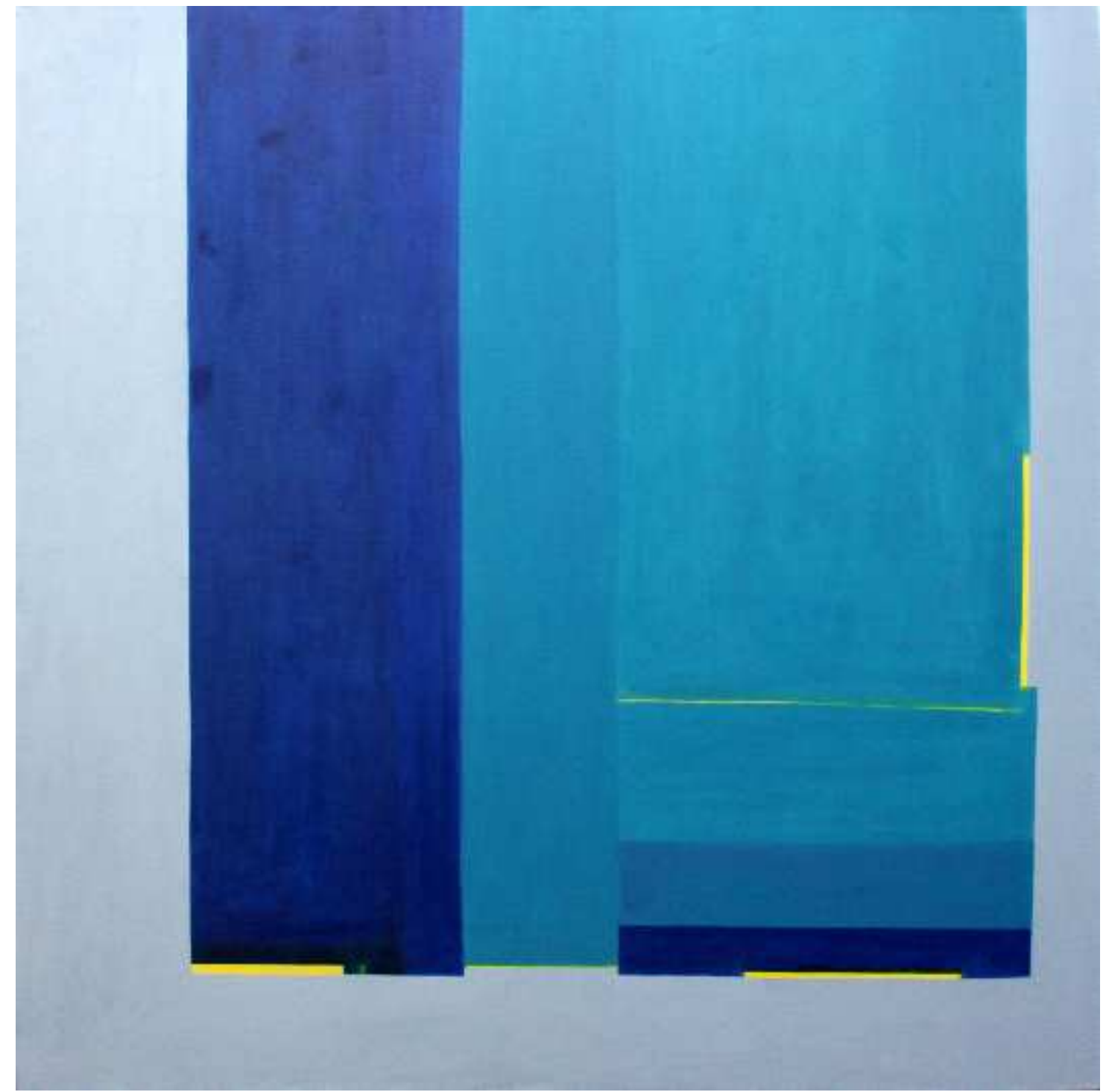




\section{Bibliografia}

AGUIAR, Vera Teixeira de. O verbal e o não verbal. São Paulo: UNESP, 2004.

ANTREASIAN, Garo Z., ADAMS, Clinton. The tamarind book of litography: Art \& Techniques. Los Angeles: Tamarind Lithography Workshop, 1971.

ARGAN, Giulio Carlo. Arte moderna : do lluminismo aos movimentos contemporâneos. São Paulo: Companhia das Letras, 1996

História da arte como história da cidade. São Paulo: Martins Fontes, 2005.

ARNHEIM, Rudolf. Intuição e intelecto na arte. São Paulo: Martins Fontes, 1989.

BARTHES, Roland. O Prazer do Texto. São Paulo: Editora Perspectiva, 2004.

BAUDELAIRE, Charles, O Pintor da Vida Moderna IN Baudelaire, C. A Modernidade de Baudelaire. Rio de Janeiro: Paz e Terra, 1988.

BERGSON, Henri. Matéria e memória. São Paulo: Martins Fontes, 1999

BERMAN, Marshall. Tudo que é sólido desmancha no ar: a aventura da modernidade. São Paulo: Companhia das letras, 1986.

BOLLE, Willi. Fisiognomia da metrópole moderna: representação da história em Walter Benjamin. São Paulo : Edusp, 1994.

BRITO, Ronaldo. Neoconcretismo: vértice e ruptura do projeto construtivo brasileiro. Rio de Janeiro: FUNARTE / Instituto Nacional de Artes Plásticas, 1985.

CALVINO, Ítalo. As cidades invisíveis. São Paulo: Companhia das Letras, 1990.

ECO, Humberto. Como se faz uma tese. São Paulo: Perspectiva, 1996.

FRANCASTEL, Pierre. A realidade figurativa. São Paulo: Perspectiva, 1973. 
GELDZAHLER, Henry. Making it new: essays interviews and talks. New York: Turtle Point Press, 1994.

GOMBRICH, Ernst Hans. A história da arte. Rio de Janeiro : LTC, 1999.

Arte e ilusão: um estudo da psicologia da representação pictórica. São Paulo: Martins Fontes, 1986.

GOMES, Renato Cordeiro. Todas as cidades, a cidade. Rio de Janeiro: Rocco, 1994

HUNTER, Sam. Robert Rauschenberg. New York: Rizzoli, 1999.

KOTZ, Mary Linn. Rauschenberg: art and life. New York: Abrams, 1990.

LISPECTOR, Clarice. Água Viva. São Paulo: Círculo do livro, 1973.

MILNER, John. Mondrian. New York: Phaidon Press Limited, 1992.

MONDRIAN, Piet. Declaração. In: CHIPP, Herschel Browning. Teorias da arte moderna. São Paulo: Martins Fontes, 1999.

PAREYSON, Luigi. Os Problemas da estética. São Paulo: Martins Fontes, 1989.

SALLES, Cecília Almeida. Gesto Inacabado: processo de criação artística. São Paulo: FAPESP/ Annablume, 2004.

SCHAPIRO, Meyer. Mondrian - a dimensão humana da pintura abstrata. São Paulo: Cosac Naify, 2001.

STEINBERG, Leo. Outros critérios: confrontos com a arte do século XX. São Paulo: Cosac Naify, 2008.

\section{CATÁLOGOS}

HERKENHOFF, Paulo. In: Jac Leirner. São Paulo: Galeria Camargo Vilaça, 1993.

Sprengel Museum Hannover, Pinacoteca do Estado de São Paulo, Museu Oscar Niemeyer, Curitiba e Goethe Institut (apres.). Kurt Schwitters 1887/1948: O artista merz. São Paulo: Pinacoteca do Estado, outubro de 2007; Curitiba: Museu Oscar Niemeyer, dezembro de 2007. 


\section{PUBLICAÇÃO}

PLAZA, Julio. Arte/ciência: uma consciência. in: Revista ARS. São Paulo: O Departamento (CAP-ECA-USP), Ano $1 / \mathrm{n}^{\circ} 1 /$ 2003.

VIDEO

ROBERT Rauschenberg: Man at work. Direção: Chris Granlund. BBC/ Guggenheim / RM Arts. Edição: Michael Poole. Narração: Sean Barrett. New York: 1997, 1 DVD (56 min.), COLOR.

\section{SOFTWARE}

Google Earth, 1998. Google Inc. Disponível em: <http://earthgloogle.com.br> Acesso em: 18 jul. 2009.

\section{SITE}

PEDROSA, Adriano. Slow Poltics. Disponível em: <http://www.nararoesler.com.br/textos/marco-maggi>. Acesso em: 14 jul. 2009.

\section{EXPOSIÇÃO}

Kurt Schwitters 1887/1948: O artista merz. São Paulo: Pinacoteca do Estado, de 16 de outubro a 02 de dezembro de 2007; Curitiba: Museu Oscar Niemeyer, de 14 de dezembro de 2007 a 09 de março de 2008. 